\title{
Diabetes is most important cause for mortality in COVID-19 hospitalized patients: Systematic review and meta-analysis
}

\author{
Giovanni Corona ${ }^{1}$ - Alessandro Pizzocaro ${ }^{2}$ - Walter Vena ${ }^{2} \cdot$ Giulia Rastrelli $^{3} \cdot$ Federico Semeraro $^{4} \cdot$ Andrea M Isidori $^{5}$. \\ Rosario Pivonello $^{6,7} \cdot$ Andrea Salonia $^{8,9} \cdot$ Alessandra Sforza $^{1} \cdot$ Mario Maggi $^{10}$
}

Accepted: 20 January 2021 / Published online: 22 February 2021

(c) The Author(s), under exclusive licence to Springer Science+Business Media, LLC part of Springer Nature 2021

\begin{abstract}
The presence of SARS-CoV-2 was officially documented in Europe at the end of February 2020. Despite many observations, the real impact of COVID-19 in the European Union (EU), its underlying factors and their contribution to mortality and morbidity outcomes were never systematically investigated. The aim of the present work is to provide an overview and a meta-analysis of main predictors and of country differences of severe acute respiratory syndrome coronavirus 2 (SARSCoV-2) infection-associated mortality rate (MR) in hospitalized patients. Out of 3714 retrieved articles, 87 studies were considered, including 35,486 patients (mean age 60.9 \pm 8.2 years) and 5867 deaths. After adjustment for confounders, diabetes mellitus was the best predictors of MR in an age- and sex-dependent manner, followed by chronic pulmonary obstructive diseases and malignancies. In both the US and Europe, MR was higher than that reported in Asia $(25[20 ; 29] \%$ and 20[17;23] $\%$ vs. $13[10 ; 17] \%$; both $p<0.02$ ). Among clinical parameters, dyspnea, fatigue and myalgia, along with respiratory rate, emerged as the best predictors of MR. Finally, reduced lymphocyte and platelet count, along with increased D-dimer levels, all significantly contributed to increased mortality. The optimization of glucose profile along with an adequate thrombotic complications preventive strategy must become routine practice in diseased SARS-CoV-2 infected patients.
\end{abstract}

Keywords Diabetes mellitus $\cdot$ SARS-CoV-2 $\cdot$ COVID-19 $\cdot$ male $\cdot$ testosterone $\cdot$ mortality $\cdot$ hospitalization

\section{Introduction}

Between late 2019 and early 2020 a novel coronavirus, named severe acute respiratory syndrome coronavirus 2 (SARSCoV-2), was isolated in the city of Wuhan in China [1-4]. Thereafter, the virus has rapidly spread around the world

Giovanni Corona

jocorona@libero.it

1 Endocrinology Unit, Medical Department, Azienda Usl Bologna Maggiore-Bellaria Hospital, Largo Nigrisoli, 2 - 40133 Bologna, Italy

2 Unit of Endocrinology, Diabetology and Medical Andrology, IRCSS, Humanitas Research Hospital, Rozzano, Milan, Italy

3 Female Endocrinology and Gender Incongruence Unit, Department of Experimental, Clinical and Biomedical Sciences, University of Florence, Florence, Italy

4 Department of Anaesthesia, Intensive Care and EMS, Maggiore Hospital Bologna, Bologna, Italy

5 Department of Experimental Medicine, Sapienza University of Rome - Policlinico Umberto I Hospital, Rome, Italy causing a novel type of disease named coronavirus disease 2019 (COVID-19) by the World Health Organization (WHO) in February 2020 [4]. The clinical manifestations of COVID-19 are quite variable ranging from an asymptomatic condition to lifethreatening SARS and death [1-4]. From its first description and isolation, the SARS-CoV-2 infection rapidly spread worldwide,

6 Dipartimento Di Medicina Clinica E Chirurgia, Sezione Di Endocrinologia, Unità Di Andrologia E Medicina Della Riproduzione E Della SessualitàMaschile E Femminile, Università Federico II Di Napoli, Naples, Italy

7 Staff of UNESCO, Chair for Health Education and Sustainable Development, Federico II University, Naples, Italy

8 Division of Experimental Oncology/Unit of Urology, URI, IRCCS Ospedale San Raffaele, Milan, Italy

9 University Vita-Salute San Raffaele, Milan, Italy

10 Endocrinology Unit, Department of Experimental, Clinical and Biomedical Sciences, University of Florence, Florence, Italy 
thus leading the WHO to declare the status of a pandemic condition in mid-March 2020 (https://www.euro.who.int/en/ health-topics/health-emergencies/coronavirus-covid-19/news/ news/2020/3/who-announces-covid-19-outbreak-a-pandemic). The outbreak has been putting dramatic pressure on healthcare systems worldwide resulting globally, on 1st October 2020, in 32,722,075 confirmed cases and 1,009,270 deaths (https://covid 19.who.int/).

The specific mechanisms and risk factors underlying a more severe clinical manifestation and outcomes of COVID-19, rather than a milder course, are still largely unknown. However, epidemiological data have emphasized from the beginning the possibility that older age and a large number of comorbid conditions represent common markers of higher mortality and morbidity in COVID-19 [1-4]. Diabetes mellitus (DM) and poor glucose control represent crucial factors for higher risk of worse COVID19 outcome [5-7]. Available evidence indicates that, while DM does not increase the risk of contracting COVID-19, its presence is closely related to worse outcomes, particularly in poorly controlled subjects [8-10]. Several pathogenetic mechanisms, including modulation of immune response, predisposition to severe infection, associated morbidities and common use of agents able to modulate angiotensinconverting enzyme 2 (ACE2) expression, have put forth to explain the latter association [8]. However, it is important to recognize that the vast majority of the available data regarding the role of DM on SARS-CoV2 infection derives from observational studies, preventing us from adequately addressing pathogenetic inferences [11]. Similarly, the specific contribution of the other morbidities to COVID19 mortality and morbidity is largely unknown.

Gender is another important factor to be considered in the evaluation of SARS-CoV-2 infection sequelae. In fact, despite a similar prevalence in virus infection between men and women, a well-documented, gender-related difference in terms of disease severity has been reported, with women characterized by an overall more favorable outcome, when compared to that observed in men [2,3]. In line with this view, a recent meta-analysis, considering epidemiological data from six countries, including England, Israel, Italy, Spain and the US, showed that men had a higher risk of fatality rate, regardless of age, when compared to women [12]. The reasons for such associations are probably multifactorial and still largely unknown. Social and cultural behaviors reported in men, including higher frequency of smoking habits and alcohol intake, along with higher prevalence of comorbidities, have all been considered as possible, gender-related risk factors [13]. Furthermore, the contribution of hormones and, in particular, of testosterone $(\mathrm{T})$, has been object of an intense debate in the scientific literature [13-15]. However, emerging evidence supports that low $\mathrm{T}$, rather than high $\mathrm{T}$, can better explain the higher risk for COVID-19 lethality observed in men [13-16]. In previous studies, low $\mathrm{T}$ has been associated with worse metabolic features [17-20] and with a higher risk of overall and cardiovascular (CV) mortality and morbidity in aging men [21, 22]. Hence it is possible that men with COVID-19 and low $\mathrm{T}$ are enriched with comorbidities, which can lead to unfavorable outcomes. It has been speculated that low T might not play a direct pathogenic role, but it could be considered just a resilient adaptation, turning off T-dependent functions (such as reproduction and/or physical and sexual activity) that are not desirable when the physical condition is ailing [23, 24].

The presence of SARS-CoV-2 was officially documented in Europe at the end of February 2020. Among others, Italy was one of the most affected countries, along with Spain, France and the UK [25]. Despite these observations, the real impact of COVID-19 in the European Union (EU), its underlying factors and their contribution to mortality and morbidity outcomes were never systematically investigated.

Available meta-analyses investigating the factors underlying COVID-19 mortality in hospitalized patients are of poor quality, mainly limited to the Chinese population and/ or to the first wave ofSARS-CoV-2 infection [26-29]. Both data related to non-Chinese subjects and possible comparisons among different countries are actually poorly reported [30-34]. Using a meta-analytic method, the aim of the present study is to provide an overview of the main predictors of mean mortality rate (MR) related to SARS-CoV-2 infection in hospitalized patients, according to available published data. In addition, the contribution of the associated morbidities, age and gender to COVID-19 outcomes in the same population will be also analyzed. Finally, possible differences among countries analyzed will be investigated.

\section{Methods}

This meta-analysis was performed in line with the Preferred Reporting Items for Systematic Reviews and Meta-Analyses (PRISMA) reporting guideline [see Supplementary file 1]. The protocol of this study (CRD42020193145) was published on the website of the University of York (Centre for Reviews and Dissemination) https://www.crd.york.ac.uk/PROSPERO.

\section{Search strategy}

An extensive Medline, Embase and Cochrane search was performed, including the following words: "covid"[All Fields] AND ("mortality"[MeSH Terms] OR "mortality"[All Fields] OR "mortalities"[All Fields] OR "mortality"[MeSH Subheading]). 
The search, which accrued data from January 1st, 2020 up to July 31, 2020, was restricted to English-language articles and studies including human participants. The identification of relevant studies was performed independently by three of the authors (W.V, A.P, G.R), and conflicts were resolved by the first investigator (G.C). All the data identified during the first analysis were checked in a second wave analysis by two of the authors (F.S, A.S). Possible further conflicts were discussed and resolved by the first investigator (G.C). We did not employ search software but hand-searched bibliographies of retrieved papers for additional references. All the authors adequately contributed to the analysis of the paper and reviewed the final version of the manuscript. The main source of information was derived from published articles.

\section{Study selection}

All prospective and retrospective observational studies reporting crude overall COVID-19-related MR in hospitalized subjects, without any arbitrary restriction, were included, even if mortality was not the principal endpoint (see Fig. 1 and Table 1) [1, 6, 15, 35-118]

No country restriction was applied. Data reporting mortality rate only in studies or case series of subjects not admitted to the hospital were excluded from the analysis (see Fig. 1). Studies not specifically stating the occurrence or absence of overall MR were excluded from the analysis.

\section{Outcome and quality assessment}

Primary outcome was the analysis of overall MR in patients admitted to the hospital due to symptomatic SARS-CoV-2 infection. Secondary outcomes included the comparison of overall MR according to age and to different countries analyzed. In addition, the effect of several risk factors including DM, hypertension, cardiovascular diseases as well as chronic kidney diseases (CKD) and chronic obstructive pulmonary diseases (COPD) on overall mortality was analyzed. Similarly, the impact of clinical symptoms and biochemical parameters on mortality at admission was investigated. The quality of trials included was assessed using the Cochrane criteria [119]. In particular, we evaluated the following criteria: the weaknesses of the designs that have been used (such as noting their potential to ascertain causality), the execution of the studies through a careful assessment of their risk of bias, especially the potential for selection bias and confounding to which all observational studies are susceptible, and the potential for reporting biases, including selective reporting of outcomes.

\section{Statistical analysis}

Heterogeneity in MR was assessed using $\mathrm{I}^{2}$ statistics. Even when low heterogeneity was detected, a randomeffect model was applied because the validity of tests

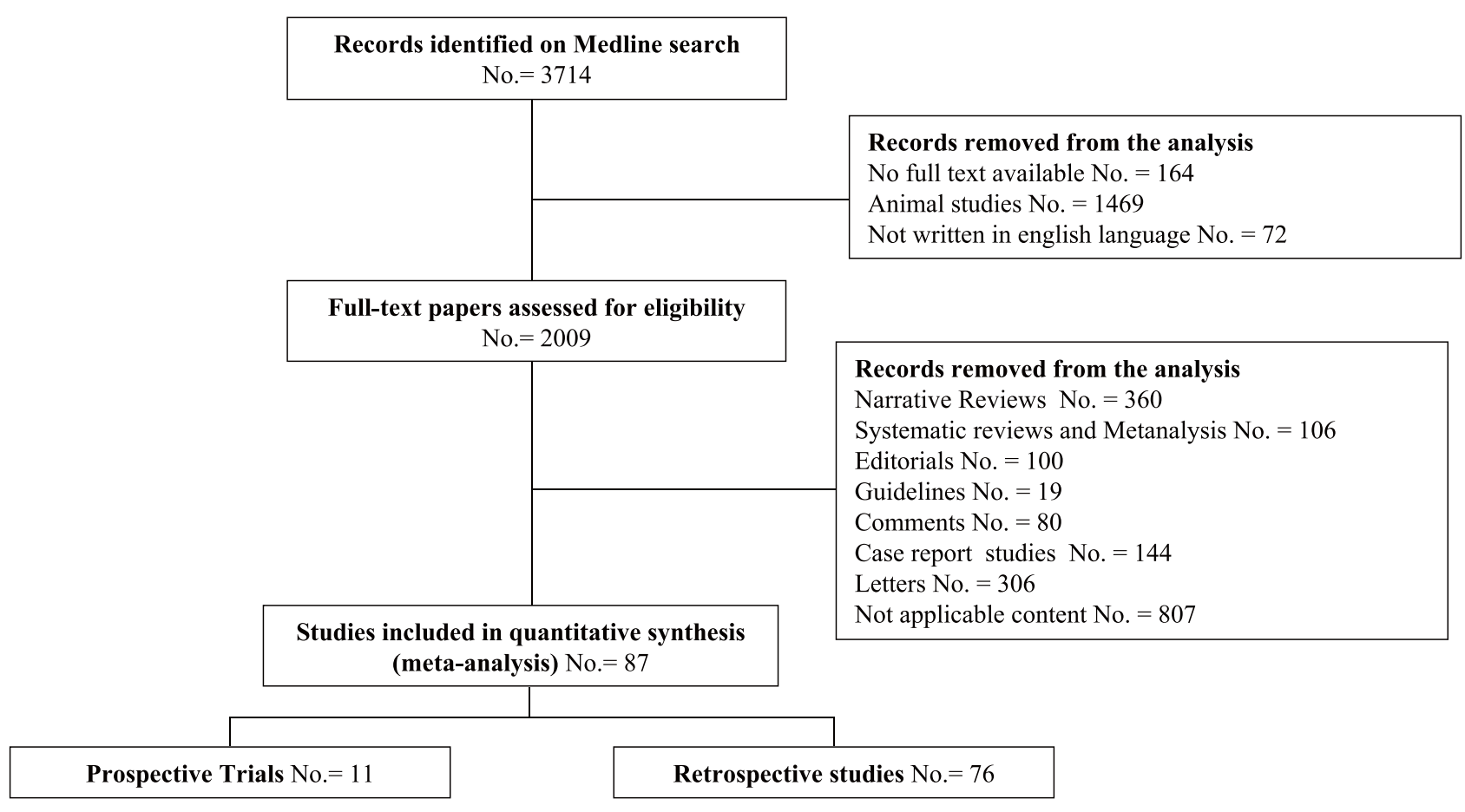

Fig. 1 Trial flow diagram for a systematic review and meta-analysis of mortality rate in hospitalized patients with COVID-19. Not applicable content $=$ paediatric population, erratum, mortality not reported, useless clinical data, national registry, autoptic case series, histo-pathological series 
Table 1 Characteristics of trials included in the meta-analysis

\begin{tabular}{|c|c|c|c|c|c|c|c|c|c|}
\hline \multirow{2}{*}{$\begin{array}{l}\text { Authors } \\
\text { Abrishami A et al. [35] }\end{array}$} & \multirow{2}{*}{$\begin{array}{l}N^{\circ} \\
\text { Pts } \\
43\end{array}$} & \multirow{2}{*}{$\begin{array}{l}\mathrm{N}^{\circ} \text { Deaths } \\
5\end{array}$} & \multirow{2}{*}{$\begin{array}{l}\text { Study Area } \\
\text { Other (Iran) }\end{array}$} & \multirow{2}{*}{$\begin{array}{l}\text { Population type } \\
\text { HI }\end{array}$} & \multicolumn{2}{|c|}{$\begin{array}{l}\text { Study } \\
\text { Design }\end{array}$} & \multirow{2}{*}{$\begin{array}{l}\text { Male (\%) } \\
65,1\end{array}$} & \multirow{2}{*}{$\begin{array}{l}\text { Follow up } \\
\text { (Months) }\end{array}$} & \multirow{2}{*}{$\begin{array}{l}\begin{array}{l}\text { Mean age } \\
\text { (years) }\end{array} \\
60,7\end{array}$} \\
\hline & & & & & $\mathrm{S}$ & $\mathrm{R}$ & & & \\
\hline Aggarwal S et al. [36] & 16 & 3 & USA (IA) & $\mathrm{HI}$ & $\mathrm{S}$ & $\mathrm{R}$ & 75 & 5 & 67 \\
\hline Alberici F et al. [37] & 20 & 5 & Europe (Italy) & $\mathrm{HI}$ & S & $\mathrm{R}$ & 80 & 4 & 59 \\
\hline Argenziano GM et al. [38] & 1000 & 211 & USA (NY) & $\mathrm{HI}$ & $S$ & $\mathrm{R}$ & 60 & 5 & 63 \\
\hline Arshad S et al. [39] & 2541 & 460 & USA (MI) & $\mathrm{HI}$ & M & $\mathrm{R}$ & 51 & 6 & 64 \\
\hline Bezzio C et al. [40] & 79 & 6 & Europe (Italy & $\mathrm{HI}$ & M & $\mathrm{P}$ & 56 & 7 & 45 \\
\hline Borba MGS et al. [41] & 81 & 22 & Other (Brasil) & $\mathrm{HI}$ & $\mathrm{S}$ & $\mathrm{P}$ & 75 & 4 & 51,1 \\
\hline Burns GP et al. [42] & 28 & 14 & Europe (UK) & $\mathrm{HI}$ & $S$ & $\mathrm{R}$ & 53,6 & 7 & 81,5 \\
\hline Campochiaro C et al. [43] & 65 & 16 & Europe (Italy) & HI, ICU & $S$ & $\mathrm{R}$ & 81 & 6 & 63,3 \\
\hline Cao B et al. [44] & 199 & 44 & Asia (China) & $\mathrm{HI}$ & $S$ & $\mathrm{P}$ & 60 & 3 & 58 \\
\hline Capra R et al. [45] & 85 & 13 & Europe (Italy) & HI & $S$ & $\mathrm{R}$ & 75 & 5 & 65 \\
\hline Cheng Y et al. [46] & 701 & 113 & Asia (China) & $\mathrm{HI}$ & $S$ & $\mathrm{R}$ & 52 & 3 & 63 \\
\hline Chilimuri S et al. [47] & 375 & 160 & USA (NY) & HI & S & $\mathrm{R}$ & 63 & 7 & 63 \\
\hline Chung MS et al. [48] & 110 & 6 & Asia (South Korea) & HI, ICU & $S$ & $\mathrm{R}$ & 43,6 & 6 & 56,9 \\
\hline Cui X et al. [49] & 116 & 24 & Asia (China) & $\mathrm{HI}$ & M & $\mathrm{R}$ & 56,9 & 7 & 59,2 \\
\hline De Smet R et al. [50] & 81 & 19 & Europe (Belgium) & $\mathrm{HI}$ & $\mathrm{S}$ & $\mathrm{R}$ & 41 & 6 & 85 \\
\hline Du RH et al. [51] & 179 & 21 & Asia (China) & $\mathrm{HI}$ & $\mathrm{S}$ & $\mathrm{P}$ & 54 & 3 & 57,6 \\
\hline Feng Y et al. [52] & 476 & 38 & Asia (China) & HI & M & $\mathrm{R}$ & 57 & 6 & 53 \\
\hline Gao S et al. [53] & 210 & 35 & Asia (China) & $\mathrm{HI}$ & S & $\mathrm{R}$ & 48 & 6 & 71 \\
\hline Gregoriano C et al. [54] & 99 & 18 & Europe (Switzerland) & HI, ICU & $S$ & $\mathrm{R}$ & 63 & 7 & 67 \\
\hline Grein J et al. [55] & 53 & 7 & Asia, Canada, Europe, USA & $\mathrm{HI}$ & $S$ & $\mathrm{R}$ & 75 & 6 & 64 \\
\hline Hong KS et al. [56] & 98 & 5 & Asia (South Korea) & HI & $S$ & $\mathrm{R}$ & 39 & 5 & 55,4 \\
\hline Huang M et al. [57] & 60 & 0 & Asia (China) & ICU & M & $\mathrm{R}$ & 58,3 & 7 & 57 \\
\hline Inciardi $\mathrm{M}$ et al. [58] & 99 & 26 & Europe (Italy) & $\mathrm{HI}$ & $\mathrm{S}$ & $\mathrm{R}$ & 81 & 5 & 67 \\
\hline Israelsen SB et al. [59] & 175 & 43 & Europe (Denmark) & HI & $S$ & $\mathrm{R}$ & 49 & 6 & 71 \\
\hline Itelman E et al. [60] & 162 & 5 & Other (Israel) & HI & $\mathrm{S}$ & $\mathrm{R}$ & 65 & 5 & 52 \\
\hline Jang JG et al. [61] & 110 & 6 & Asia (South Korea) & HI & $\mathrm{S}$ & $\mathrm{R}$ & 43,6 & 6 & 56,9 \\
\hline Lagi F et al. [62] & 84 & 8 & Europe (Italy) & HI & $\mathrm{S}$ & $\mathrm{R}$ & 65 & 5 & 62 \\
\hline Lecronier $\mathrm{M}$ et al. [63] & 80 & 25 & Europe (France) & ICU & $S$ & $\mathrm{R}$ & 80 & 7 & 57 \\
\hline Lewnard JA et al. [64] & 1095 & 202 & USA (CA, WA) & HI & M & $\mathrm{P}$ & 56 & 5 & 61 \\
\hline Li L et al.[65] & 93 & 25 & Asia (China) & $\mathrm{HI}$ & $\mathrm{S}$ & $P$ & 44 & 5 & 51 \\
\hline Li R et al. [66] & 225 & 2 & Asia (China) & HI & S & $\mathrm{R}$ & 53 & 6 & 50 \\
\hline Li X et al. [67] & 8 & 4 & Asia (China) & ICU & $S$ & $\mathrm{R}$ & 75 & 5 & 64,25 \\
\hline Liu X et al. [68] * & 39 & 2 & Asia (China) & ICU & $\mathrm{S}$ & $\mathrm{R}$ & 64 & 7 & 64 \\
\hline Liu X et al., $[68]^{* *}$ & 40 & 9 & Asia (China) & $\mathrm{HI}$ & $\mathrm{S}$ & $\mathrm{R}$ & 63 & 7 & 61 \\
\hline McMichael TM et al. [69] & 81 & 22 & USA (WA) & LTC & $\mathrm{S}$ & $\mathrm{R}$ & 35 & 3 & 81 \\
\hline Meng Y et al. [70] & 168 & 17 & Asia (China) & HI, ICU & $\mathrm{S}$ & $\mathrm{R}$ & 51 & 4 & 56,7 \\
\hline Miyashita S et al. [71] & 2071 & 429 & USA (NY) & Mixed & $\mathrm{S}$ & $\mathrm{R}$ & 43,9 & 7 & \\
\hline Moghaddam A et al. [72] & 33 & 6 & Europe (Germany) & $\mathrm{HI}$ & $\mathrm{S}$ & $\mathrm{P}$ & 42 & 7 & 77 \\
\hline Morena V et al. [73] & 51 & 14 & Europe (Italy) & $\mathrm{HI}$ & $\mathrm{S}$ & $\mathrm{P}$ & 78 & 5 & 60 \\
\hline Myrstad M et al. [74] & 66 & 13 & Europe (Norway) & $\mathrm{HI}$ & $\mathrm{S}$ & $\mathrm{P}$ & 57,5 & 7 & 67,9 \\
\hline Na KR et al. [75] & 66 & 0 & Asia (South Korea) & $\mathrm{HI}$ & $S$ & $\mathrm{R}$ & 53 & 7 & 45,6 \\
\hline Nightingale R et al. [76] & 24 & 5 & Europe (UK) & $\mathrm{HI}$ & $\mathrm{S}$ & $\mathrm{R}$ & 88 & & 52 \\
\hline Nikpouraghdam $\mathrm{M}$ et al. [77] & 2964 & 239 & Other (Iran) & HI & $\mathrm{S}$ & $\mathrm{R}$ & 66 & 5 & 55,5 \\
\hline Nowak B et al. [78] & 169 & 44 & Europe (Poland) & $\mathrm{HI}$ & $\mathrm{S}$ & $\mathrm{R}$ & 51 & 5 & 63,7 \\
\hline Pan F et al. [79] & 124 & 41 & Asia (China) & $\mathrm{HI}$ & $\mathrm{S}$ & $\mathrm{R}$ & 50,8 & & 56 \\
\hline Pei G et al. [80] & 333 & 29 & Asia (China) & $\mathrm{HI}$ & $\mathrm{S}$ & $\mathrm{R}$ & 55 & 6 & 56,3 \\
\hline Pellaud C et al. [81] & 196 & 32 & Europe (Switzerland) & $\mathrm{HI}$ & M & $\mathrm{R}$ & 61 & 7 & 70 \\
\hline Rastrelli G et al. [15] & 31 & 2 & Europe (Italy) & $\mathrm{HI}$ & $\mathrm{S}$ & $\mathrm{R}$ & 100 & 5 & 66,2 \\
\hline
\end{tabular}


Table 1 (continued)

\begin{tabular}{|c|c|c|c|c|c|c|c|c|c|}
\hline \multirow{2}{*}{$\begin{array}{l}\text { Authors } \\
\text { Ren H et al. [82] }\end{array}$} & \multirow{2}{*}{$\begin{array}{l}\mathrm{N}^{\circ} \\
\text { Pts }\end{array}$} & \multirow{2}{*}{$\begin{array}{l}\mathrm{N}^{\circ} \text { Deaths } \\
33\end{array}$} & \multirow{2}{*}{$\begin{array}{l}\text { Study Area } \\
\text { Asia (China) }\end{array}$} & \multirow{2}{*}{$\begin{array}{l}\text { Population type } \\
\text { HI }\end{array}$} & \multicolumn{2}{|c|}{$\begin{array}{l}\text { Study } \\
\text { Design }\end{array}$} & \multirow{2}{*}{$\begin{array}{l}\text { Male (\%) } \\
52\end{array}$} & \multirow{2}{*}{$\begin{array}{l}\text { Follow up } \\
\text { (Months) }\end{array}$} & \multirow{2}{*}{$\begin{array}{l}\begin{array}{l}\text { Mean age } \\
\text { (years) }\end{array} \\
59,5\end{array}$} \\
\hline & & & & & $\mathrm{S}$ & $\mathrm{R}$ & & & \\
\hline Ruan Q et al. [83] & 150 & 68 & Asia (China) & $\mathrm{HI}$ & M & $\mathrm{R}$ & 68,1 & 2 & 57,7 \\
\hline Satlin MJ et al. [84] & 141 & 32 & USA (NY) & $\mathrm{HI}$ & M & $\mathrm{R}$ & 63 & 7 & 62 \\
\hline Senkal N et al. [85] & 156 & 12 & Europe (Turkey) & $\mathrm{HI}$ & $\mathrm{S}$ & $\mathrm{R}$ & 53,2 & 7 & 63,7 \\
\hline Shao F et al. [86] & 136 & 132 & Asia (China) & HI (SHF) & $\mathrm{S}$ & $\mathrm{R}$ & 66 & 4 & 69 \\
\hline Shi Y et al. [87] & 487 & 0 & Asia (China) & $\mathrm{HI}$ & M & $\mathrm{R}$ & 53 & 3 & 46 \\
\hline Smith AA et al. [88] & 346 & 117 & USA (CT,MA) & $\mathrm{HI}$ & M & $\mathrm{R}$ & 56,1 & 7 & 66,9 \\
\hline Song JW et al. [89] & 41 & 2 & Asia (China) & $\mathrm{HI}$ & $\mathrm{S}$ & $\mathrm{P}$ & 61 & 7 & 39 \\
\hline Steinberg E et al. [90] & 210 & 18 & USA (NJ) & $\mathrm{HI}$ & 2 & $\mathrm{R}$ & & 7 & \\
\hline Tang N et a. [91] & 449 & 134 & Asia (China) & $\mathrm{HI}$ & $\mathrm{S}$ & $\mathrm{R}$ & 60 & 3 & 65,1 \\
\hline Tharakan S et al. [92] & 7614 & 1286 & USA (NY) & HI & M & $\mathrm{R}$ & 54,2 & 7 & 59,4 \\
\hline Trigo J et al. [93] & 576 & 127 & Europe (Spain) & $\mathrm{HI}$ & $\mathrm{S}$ & $\mathrm{R}$ & 56,7 & 4 & 67,2 \\
\hline Vuagnat P et al. [94] & 59 & 4 & Europe (France) & $\mathrm{HI}$ & $\mathrm{S}$ & $\mathrm{P}$ & 0 & 5 & 58 \\
\hline Wang B et al. [95] & 36 & 14 & USA (NY) & $\mathrm{HI}$ & $S$ & $\mathrm{R}$ & 63,7 & 7 & 69,8 \\
\hline Wang L et al. [96] & 339 & 65 & Asia (China) & $\mathrm{HI}$ & $S$ & $\mathrm{R}$ & 49 & 3 & 69 \\
\hline Wang L et al. [97]*** & 116 & 7 & Asia (China) & $\mathrm{HI}$ & $\mathrm{S}$ & $\mathrm{R}$ & 58 & 3 & 54 \\
\hline Wang Y et al. [98] & 344 & 133 & Asia (China) & ICU & $\mathrm{S}$ & $\mathrm{R}$ & 52 & 6 & 64 \\
\hline Xie J et al. [99] & 140 & 36 & Asia (China) & $\mathrm{HI}$ & $S$ & $\mathrm{R}$ & 51 & 4 & 60 \\
\hline $\mathrm{Xu} \mathrm{J}$ et al. [100] & 239 & 147 & Asia (China) & $\mathrm{HI}$ & M & $\mathrm{R}$ & 59,8 & 7 & 62,5 \\
\hline Xu PP et al. [101] & 703 & 33 & Asia (China) & $\mathrm{HI}$ & M & $\mathrm{R}$ & 54 & 5 & 46,1 \\
\hline Xu X et al. [102] & 21 & 0 & Asia (China) & $\mathrm{HI}$ & M & $\mathrm{R}$ & 86 & 4 & 56,8 \\
\hline Yan Y et al. [103] & 193 & 108 & Asia (China) & HI & $\mathrm{S}$ & $\mathrm{R}$ & 59 & 4 & 64 \\
\hline Yang BY et al. [104] & 124 & 65 & USA (WA) & Mixed & $\mathrm{S}$ & $\mathrm{R}$ & 46,8 & 7 & 75,7 \\
\hline Yang Q et al. [105] & 226 & 50 & Asia (China) & HI & $\mathrm{S}$ & $\mathrm{R}$ & 50 & 7 & 53,88 \\
\hline Yang X et al. [106] & 1476 & 238 & Asia (China) & $\mathrm{HI}$ & $S$ & $\mathrm{R}$ & 53 & 6 & 57 \\
\hline Ye W et al. [107] & 349 & 36 & Asia (China) & HI & S & $\mathrm{R}$ & 49,6 & 7 & 62 \\
\hline Yuan M et al. [108] & 27 & 10 & Asia (China) & HI & $S$ & $\mathrm{R}$ & 44 & 3 & 60 \\
\hline Zhang G [109] & 221 & 12 & Asia (China) & HI & $S$ & $\mathrm{R}$ & 49 & 4 & 55 \\
\hline Zhang J et al. [110] & 663 & 25 & Asia (China) & $\mathrm{HI}$ & $S$ & $\mathrm{R}$ & 48 & 4 & 55,6 \\
\hline Zhang J et al. [111] $]^{* * *}$ & 108 & 1 & Asia (China) & HI & S & $\mathrm{R}$ & 55,6 & 7 & 66 \\
\hline Zhang L et al. [112] & 343 & 13 & Asia (China) & HI & $\mathrm{S}$ & $\mathrm{R}$ & 49 & 4 & 62 \\
\hline Zhang P et al. [113]* & 188 & 16 & Asia (China) & HI & M & $\mathrm{R}$ & 53 & 6 & 64 \\
\hline Zhang P et al. [113]** & 940 & 82 & Asia (China) & $\mathrm{HI}$ & M & $\mathrm{R}$ & 54 & 6 & 64 \\
\hline Zhang S et al. [114] & 828 & 146 & Asia (China) & $\mathrm{HI}$ & M & $\mathrm{R}$ & 53,9 & 7 & 62 \\
\hline Zhang SY et al. [115] & 788 & 0 & Asia (China) & HI, ICU & $S$ & $\mathrm{R}$ & 59,9 & 7 & 45,8 \\
\hline Zhao XY et al. [116] & 91 & 2 & Asia (China) & $\mathrm{HI}$ & $\mathrm{S}$ & $\mathrm{R}$ & 54 & 4 & 46 \\
\hline Zhou F et al. [1] & 191 & 54 & Asia (China) & $\mathrm{HI}$ & M & $\mathrm{R}$ & 62 & 3 & 56 \\
\hline Zhu L et al., [6]* & 282 & 3 & Asia (China) & $\mathrm{HI}(\mathrm{CDM})$ & M & $\mathrm{R}$ & 48 & 6 & 62 \\
\hline Zhu L et al. [6]** & 528 & 58 & Asia (China) & HI (UDM) & M & $\mathrm{R}$ & 56 & 6 & 63 \\
\hline Zhu L et al. [117]*** & 10 & 1 & Asia (China) & HI (RT) & $S$ & $\mathrm{R}$ & 80 & 4 & 76 \\
\hline Zou X et al. [118] & 154 & 52 & Asia (China) & $\mathrm{HI}$ & $\mathrm{S}$ & $\mathrm{R}$ & 43,5 & 7 & 60,6 \\
\hline
\end{tabular}

$\S$ Asia (Japan), Canada (ON), Europe (Austria, France, Germany, Italy, Netherlands, Spain), USA (CA, IL, NY, RI, WA)

$H I$ Hospital Inpatients, LTC Long-Term Care, ICU Intensive Care Unit, Mixed Inpatients and Outpatients, $R$ retrospective, $P$ prospective, $S$ single center, $M$ multi-center

*same study cohort, different groups, **same study cohort, different groups, ***same name but different study

of heterogeneity can be limited with a small number of component studies. We used funnel plots and the Begg adjusted rank correlation test to estimate possible publication or disclosure bias [120]; however, undetected bias may still be present, because these tests have low statistical power when the number of trials is small. Overall 
mortality is expressed as mean percentage ( $95 \%$ confidence interval).

In addition, a meta-regression analysis was performed to test the effect of different parameters on overall mortality. Finally, a linear regression analysis model, weighting each study for the number of subjects enrolled, was performed to verify the independent effect of specific parameters on overall mortality, after the adjustment for confounders. Following on that, potential predictors of overall mortality were included as continuous variables: associated morbidities (including hypertension, DM, COPD, cardiovascular diseases, CVD, $\mathrm{CKD}$, and active malignancies), as well as clinical symptoms (including fever, cough, dyspnea and fatigue, myalgia, sore through, and gastro-intestinal symptoms) and laboratory parameters (including white, lymphocyte and platelet blood count, hemoglobin levels, C-reactive protein and D-dimer levels). All data were calculated using Comprehensive Metaanalysis Version 2, Biostat (Englewood, NJ, USA). Linear regression analysis was performed on SPSS (Statistical Package for the Social Sciences; Chicago, USA) for Windows 22.5.

\section{Results}

\subsection{General descriptive data}

Out of 3714 retrieved articles, 87 were included in the study (Table 1). Among them, 11 prospectively investigated the MR, whereas only a retrospective data analysis had been performed in the remaining 76 studies (Table 1). The study flow is summarized in Fig. 1. Among the included studies, 48 were from Asia (44 from China, and four from South Korea, respectively), 21 from Europe (eight from Italy, two from the UK, France and Switzerland, and one from Denmark, Germany, Poland, Turkey, Belgium, Spain and Norway, respectively), 13 from the US, and four from other countries (two from Iran, and one from Israel and Brazil, respectively). In addition, one study included a multicenter evaluation, including Japan, US, Canada and Europe (see Table 1). The characteristics of the retrieved trials (including parameters on trial quality) are reported in Tables 1 and 2 and in Supplementary Table 1. Retrieved trials included 35,486 patients and 5867 deaths. Mean age of population included was $60.9 \pm 8.2$ years, with males more prevalent than females $(57.7 \pm 13.5 \%)$. Finally, mean follow up was $38.4 \pm 9.0$ days.

The $\mathrm{I}^{2}$ in trials assessing overall mortality was 95.3 $(p<0.0001)$. Mean crude MR was $17[15 ; 19] \%$ (Fig. 2). A funnel plot and Begg adjusted rank correlation test (Kendall's $\tau:-0.18 ; p=0.01$ ) suggested publication bias (Supplementary Fig. 1). However, when applying Duval and Tweedie's trim and fill method, the MR was not meaningfully affected $(\mathrm{MR}=20[18 ; 23] \%)$. Both the US and European MR was higher when compared to that reported in Asia $(\mathrm{Q}=15.73$ and
$\mathrm{Q}=6.59$ for US vs. Asia and for Europe vs. Asia, respectively; both $p<0.02$ ). The US MR was also higher than that observed in other counties $(\mathrm{Q}=6.25, p<0.02$ for US vs. others), while this comparison did not reach statistical significance for Europe $(\mathrm{Q}=3.28 ; p=0.07$ for Europe vs. others). No difference in MR between Europe and the US was observed, although a trend toward a higher MR in the US was detected $(\mathrm{Q}=2.91$; $p=0.08$; see also Fig. 2 and Supplementary Fig. 2 panels A-D). No significant differences in MR were observed when retrospective studies were compared to prospective ones $(\mathrm{MR}=17[14 ; 19] \%$ vs. $18[14 ; 22] \%$, respectively; $\mathrm{Q}=0.30$, $p=0.58$ ) or when multicenter were compared to single center studies (MR $=17[15 ; 20] \%$ vs. $15[12 ; 19] \% ; \mathrm{Q}=1.11 p=0.29$ ). Finally, similar data were detected in a sensitivity analysis after excluding those studies ( $n=2$, see Table 1$)$ analyzing a mixed population of hospitalized and non-hospitalized patients $(\mathrm{MR}=17[15 ; 19] \%)$ or when high quality studies were compared to low-moderate ones $(\mathrm{MR}=14[10: 17]$ vs. $17[15 ; 20]$ respectively; $\mathrm{Q}=3.13, p=0.08$ ).

Meta-regression analysis showed that MR was significantly higher in older subjects and in those studies enrolling a larger proportion of males (see Table 1 and Supplementary Fig. 3, panels A and B). Accordingly, the MR progressively increased as a function of age decades $(\mathrm{Q}=15.51,26.35,27.19$ for $50-60,60-70$ or over 70 vs. 30-40 years old; all $p<0.0001$; see also Fig. 2). The association between MR and male gender was confirmed in a multivariate linear regression analysis, weighting each study for the number of subjects enrolled, after the adjustment for age (Adj.r $=0.175 ; p<0.0001$ ).

\subsection{Associated morbidities}

Among the associated morbidities reported, arterial hypertension was the most prevalent (mean 40.8\%) followed by DM (22.3\%), CVD (18.5\%), CKD (12.0\%), active malignancies (8.2\%) and COPD (6.8\%). Metaregression analysis was applied to investigate the effect of several associated morbidities on MR. After the exclusion of those studies enrolling 100\% hypertensive subjects (Table 1 and 2), hypertension was directly associated with higher MR (Fig. 3, panel A). Similar data were observed when the impact of DM, COPD, CVD, malignancies and CKD were evaluated (Fig. 3, panel B-F). In order to verify the best predictors of MR among the different associated morbidities, a series of alternative multivariate linear regression analyses were performed, weighting each study for the number of subjects enrolled and by introducing in the same model, as possible predictors of mortality, the different associated morbidities, age, trial duration and gender. Table 3 reports the results of this analysis. All the associated morbidities tested remained significantly associated with a higher MR, even after the adjustment for confounders. Among them, DM, COPD and malignancies 
Reviews in Endocrine and Metabolic Disorders (2021) 22:275-296

281

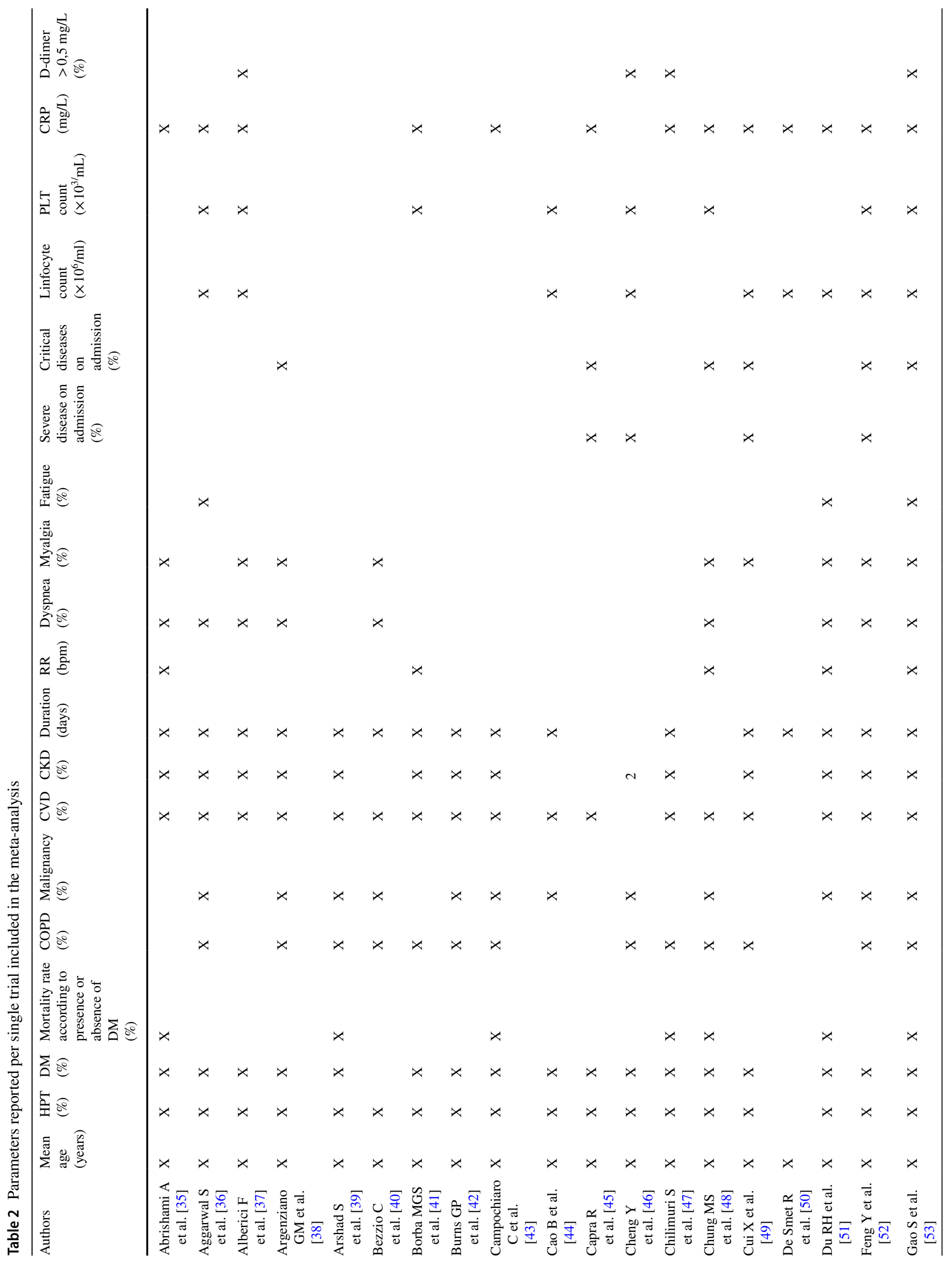

Springer 
282

Reviews in Endocrine and Metabolic Disorders (2021) 22:275-296

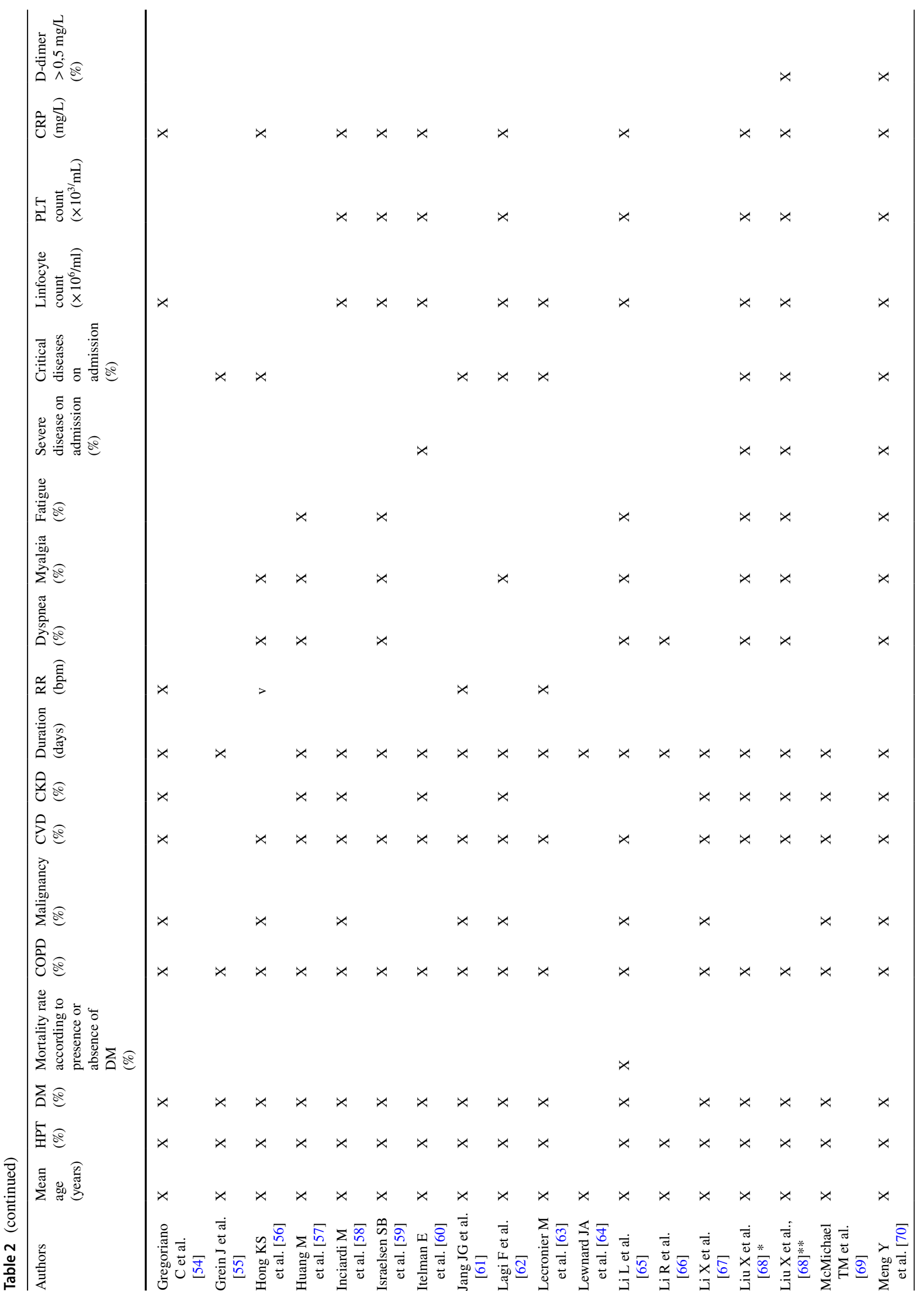

Springer 
Reviews in Endocrine and Metabolic Disorders (2021) 22:275-296

283

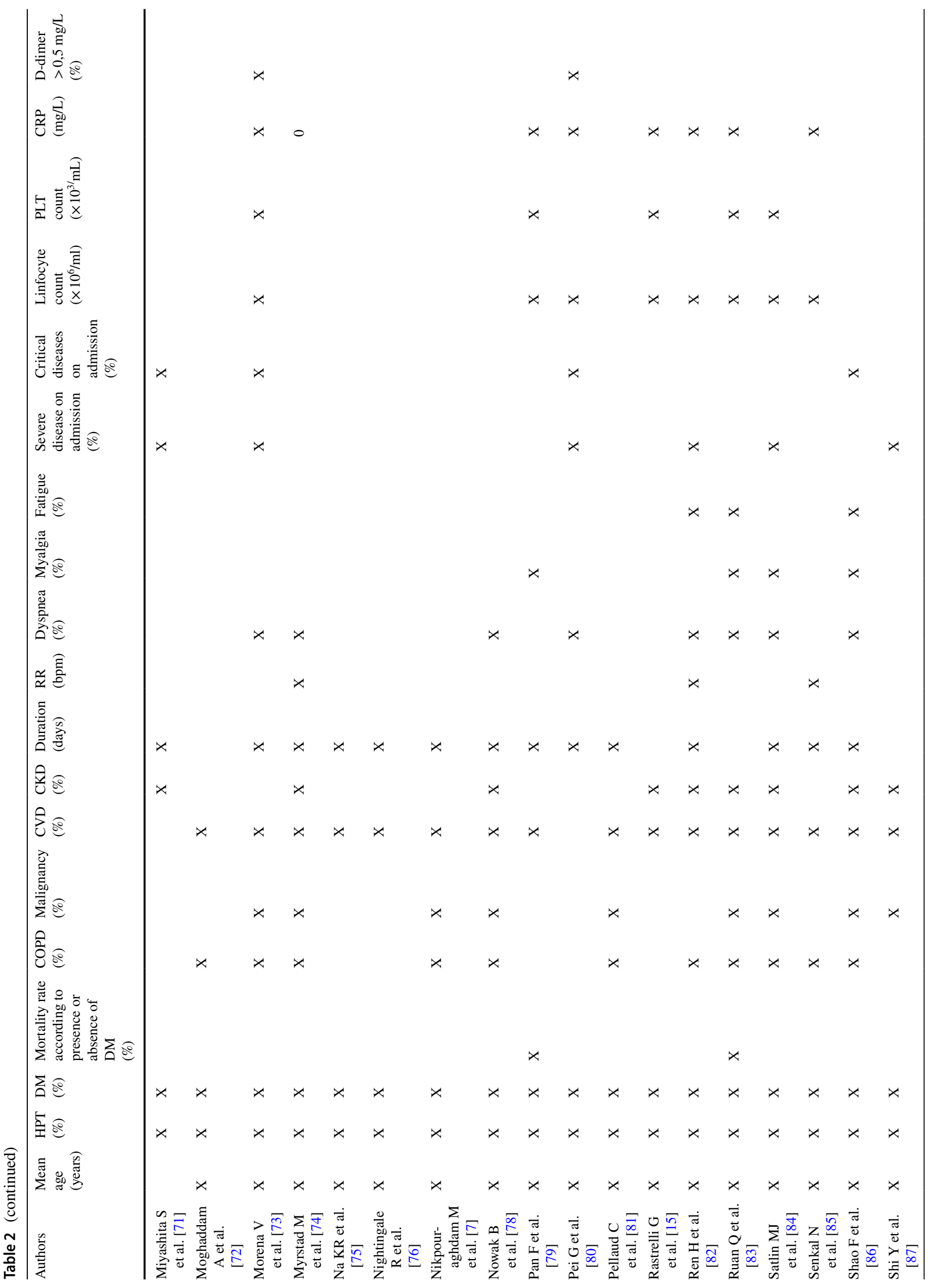

Springer 
284

Reviews in Endocrine and Metabolic Disorders (2021) 22:275-296

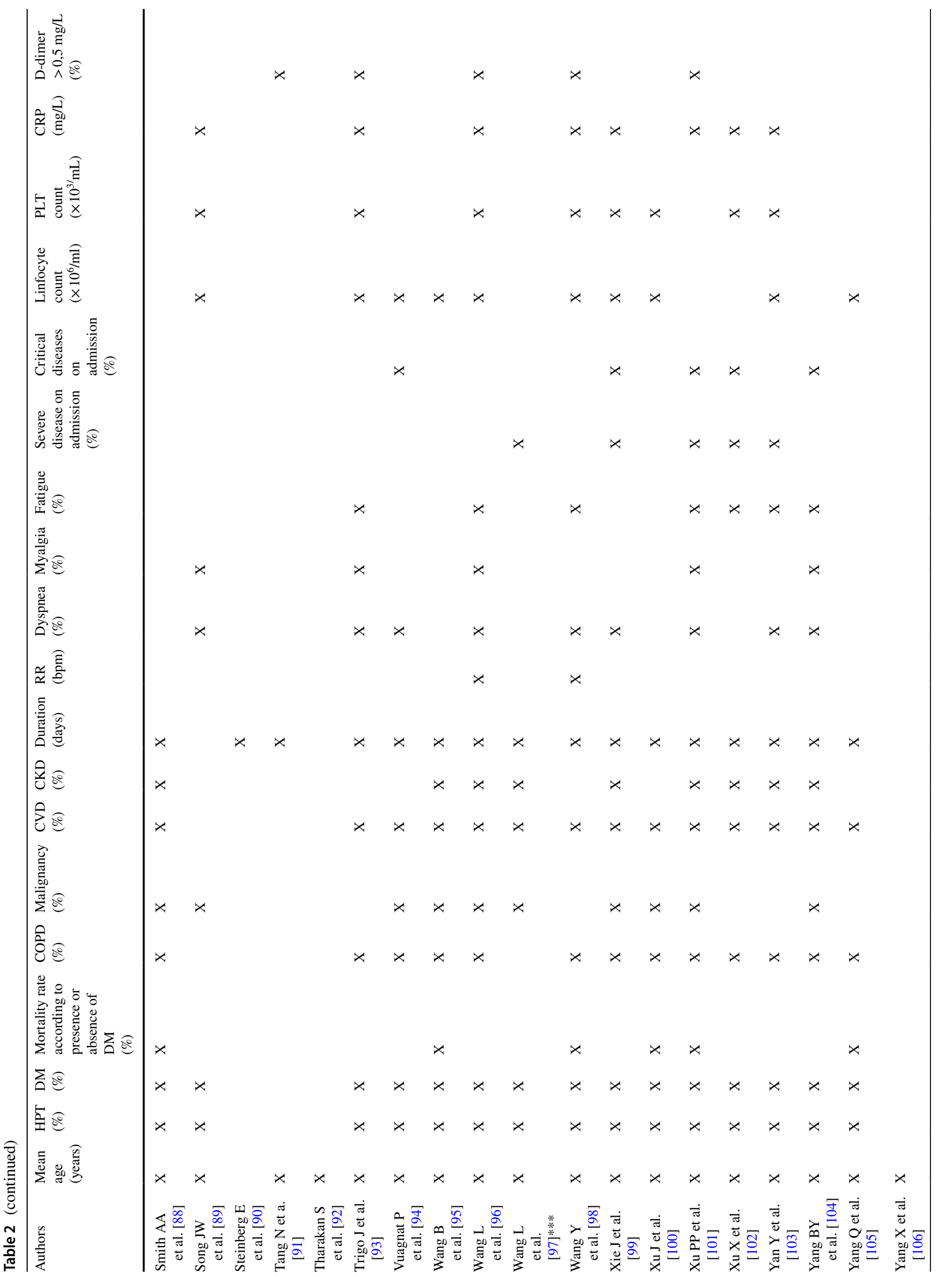

Springer 
Reviews in Endocrine and Metabolic Disorders (2021) 22:275-296

285

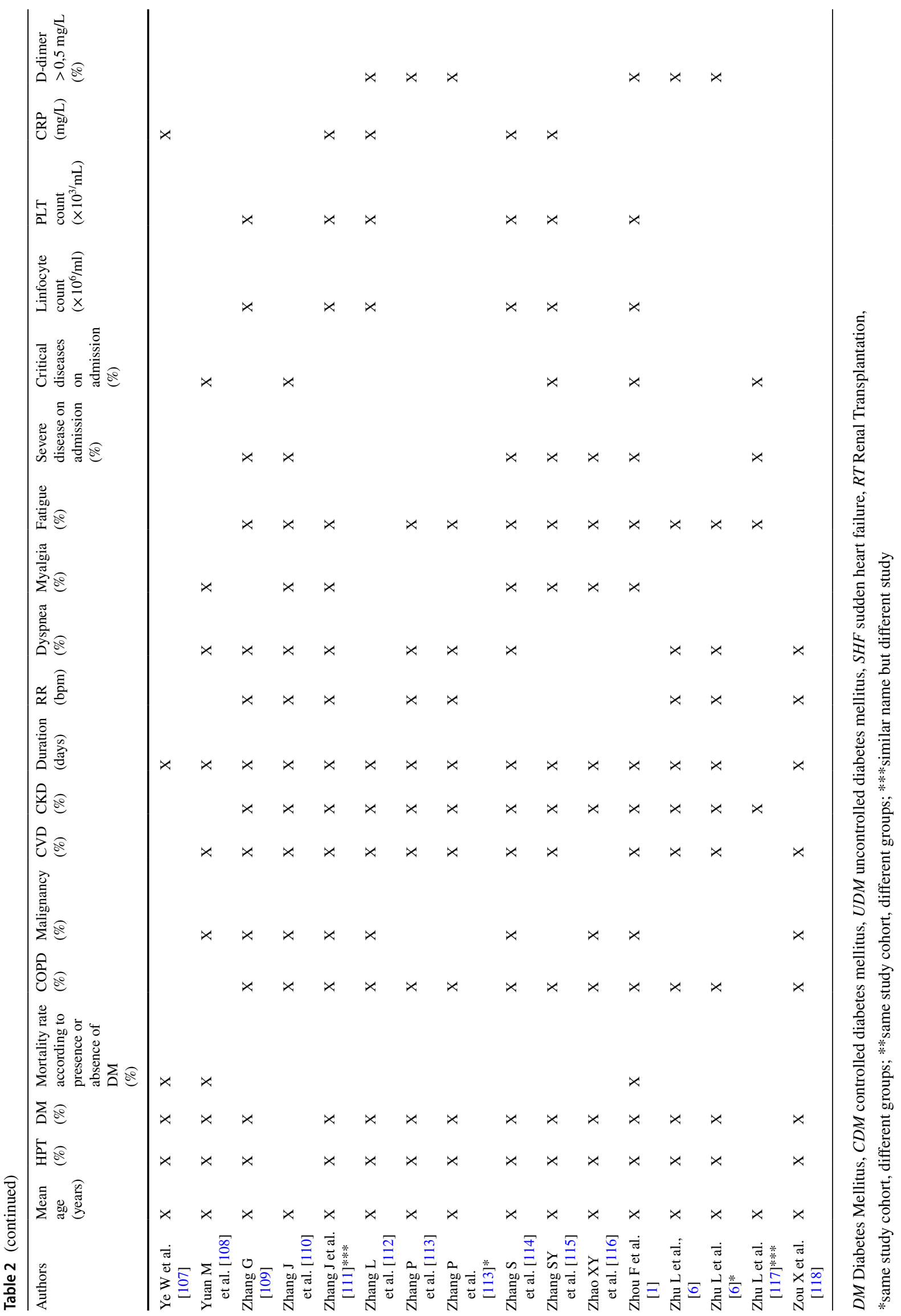

Springer 
were the strongest predictors of mortality. Interestingly, when all associated morbidities were considered in the same model with sex, along with age and study duration, as possible predictors of MR, male gender retained a high statistical significance (adj.r $=0.546 ; \mathrm{p}<0.0001)$.

\subsection{Diabetes and mortality outcomes}

Since DM was the best predictor of COVID-19 related mortality, we performed a specific sub-analysis, comparing the mortality rate in patients with or without DM. Among the available studies, 20 reported mortality rate according to the presence or absence of DM (Table 2). Overall, DM was associated with a significant increased risk of mortality, when compared to that observed in the non diabetic population (Fig. 4). Interestingly, by performing a meta-regression analysis we found that the DMincreased mortality was not related to gender and attenuated in older patients (Supplementary Fig. 4, panel A -B). In addition, when the influence of other associated morbidities was analyzed, the DM-related increased mortality was reduced in those studies reporting a higher proportion of patients with arterial hypertension or CKD (Supplementary Fig. 4, panel C-D). The latter results were confirmed even after the adjustment for age (adj.r $=-0.346$ and -0.278 for arterial hypertension and CKD, respectively; both $p<0.0001$ ). Conversely, no relationship with a previous history of CVD or COPD was observed (not shown).

\subsection{Clinical symptoms at first evaluation}

At first evaluation, a mean of $44.4 \%$ and $25.9 \%$ of the patients were defined as being in severe or critical condition, respectively. MR significantly increased as a function of the prevalence of subjects referred to hospital in severe or critical clinical condition (Supplementary Fig. 5, Panels A and B). The most common clinical symptoms reported were fever (73.5\%), cough $(64.9 \%)$, fatigue $(41.3 \%)$, dyspnea $(41.1 \%)$, myalgia $(20.2 \%)$, diarrhea $(17.2 \%)$, nausea or vomiting $(11.1 \%)$ and sore throat $(9.6 \%)$. In particular, among the clinical symptoms reported, meta-regression analysis showed that MR was directly related to subjective dyspnea and fatigue (Supplementary Fig. 5, Panel C and D), as well to respiratory rate (Supplementary Fig. 5, Panel E). In addition, a trend towards a significant direct association with myalgia was also observed (Supplementary Fig. 5, Panel F). Conversely, no association between a higher MR and other symptoms such as fever, cough, sore throat or gastro-intestinal problems (including diarrhea, nausea or vomiting) was observed (not shown). No sufficient data were available to test the impact of anosmia, dysgeusia or conjunctival congestions (not shown). The association between MR and the aforementioned clinical symptoms was confirmed in a multivariate linear regression analysis, weighting each study for the number of subjects enrolled and by introducing, in the same model, clinical symptoms and the aforementioned

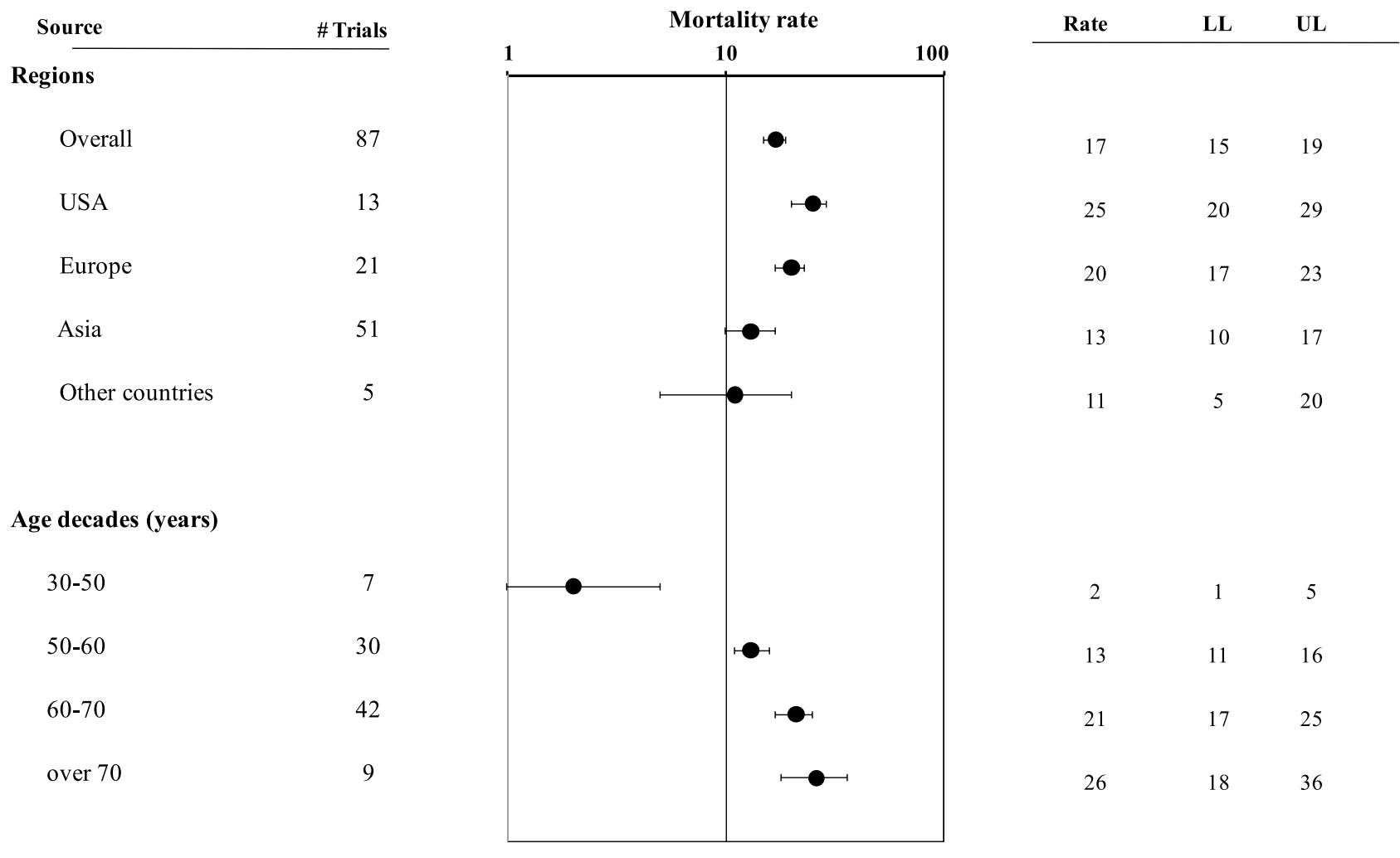

Fig. 2 Mortality rate in the whole population, in different geographical areas and as a function of age decades. LLlower levels, UP upper levels 
confounders as possible predictors of differences in MR. The results of this analysis are reported in Table 3 . All the symptoms were significantly and directly associated with a higher MR, even after the adjustment for confounders. At first evaluation, respiratory rate was the best predictor of MR (Table 3).

When the impact of the same symptoms was investigated, using meta-regression analysis, analyzing those studies reporting data as a function of DM, only the presence of a higher proportion of dyspnea was inversely related to DM-mortality rate (Supplementary Fig. 4, panel $\mathrm{E}$; adj.r $=-0.146 ; p<0.0001$ after the adjustment for age).

\subsection{Laboratory findings}

Among the different biochemical parameters evaluated, an inverse relationship between lymphocyte and platelet count and MR was observed (Fig. 5, Panel A and B). In addition, a positive association with $\mathrm{C}$-reactive protein and elevated D-Dimer levels (i.e. $>0.5 \mathrm{mg} / \mathrm{L}$ ) were also observed (Fig. 5 , Panel C and D). No association between MR and white blood count and hemoglobin levels was detected (not shown). Finally, no sufficient data were available to investigate the effect of IL-6 and Troponin I levels on MR. The associations between higher MR, reduced lymphocyte and platelet count and elevated D-Dimer levels were confirmed even after the adjustment for confounders (Table 3). Conversely, the relationship between $\mathrm{C}$-reactive protein and MR was not confirmed (not shown).

When the impact of the same parameters was evaluated, using meta-regression analysis, analysing those studies reporting data as a function of DM, lymphocyte count was inversely related to DM-mortality rate (Supplementary
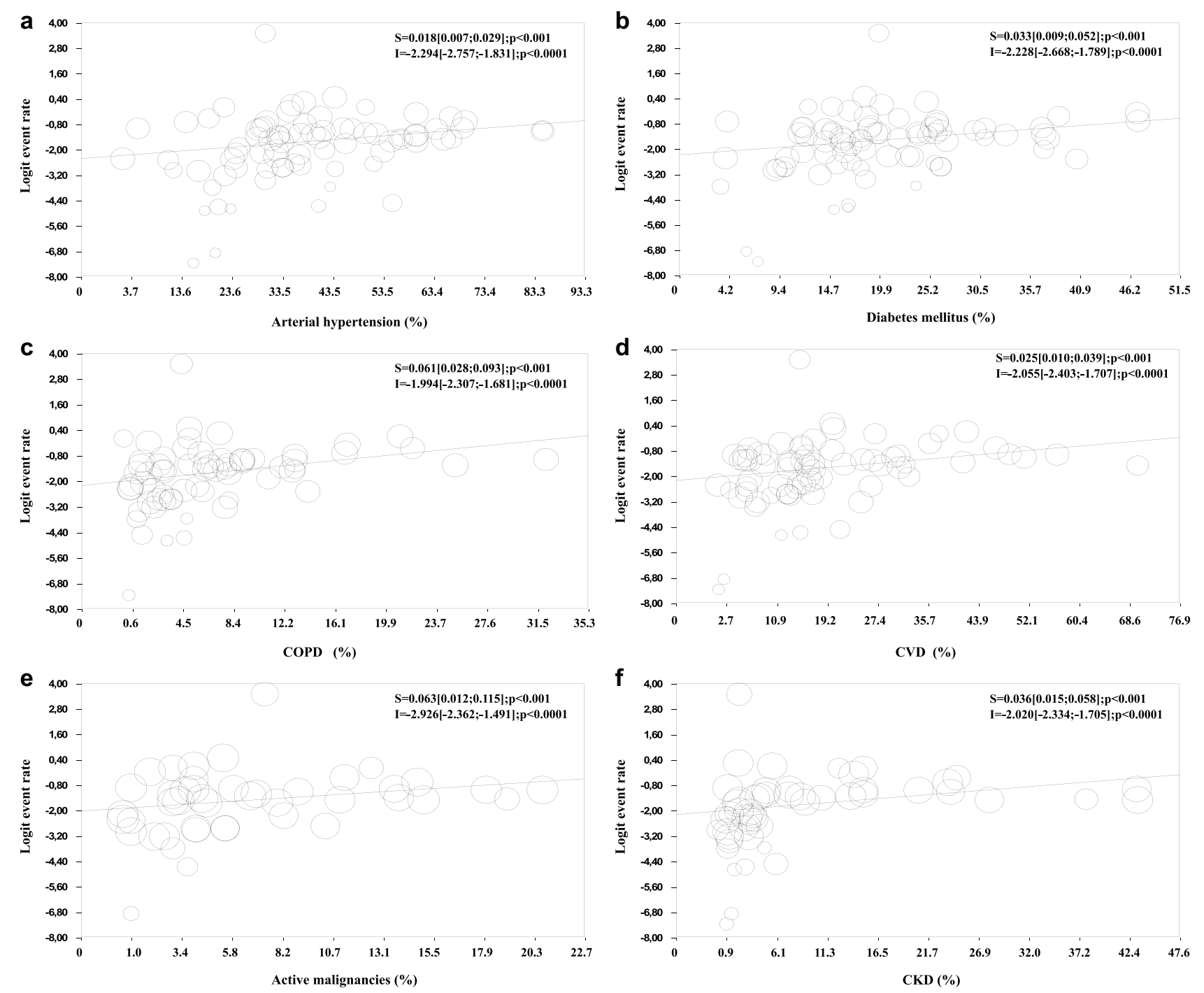

Fig. 3 Mortality rate according to different associated morbidities: arterial hypertension a, diabetes mellitus b, chronic obstructive pulmonary diseases (COPD; $)$, cardiovascular diseases (CVD; $\mathbf{d}$ ), active malignancies $\mathbf{e}$, and chronic kidney diseases (CKD; $\mathbf{f})$ 
Table 3 Adjusted relationship between end-pony mortality rate,associated morbidities, clinical symptoms and laboratory findings. Data are derived from a multivariate linear regression model, weighting each study for the number of subjects enrolled, introducing associated morbidities, age study duration and sex as possible predictors of mortality rate

\begin{tabular}{lcc}
\hline & & Mortality rate \\
\cline { 3 - 3 } & Adj r & $p$ \\
\hline Associated morbidities & & \\
Arterial hypertension & 0.059 & 0.0001 \\
Diabetes mellitus & 0.187 & 0.0001 \\
COPD & 0.138 & 0.0001 \\
Malignancies & 0.139 & 0.0001 \\
CVD & 0.068 & 0.0001 \\
CKD & 0.072 & 0.0001 \\
Clinical symptoms & & \\
Dsypnea & 0.476 & 0.0001 \\
Respiratory rate & 0.644 & 0.0001 \\
Fatigue & 0.289 & 0.0001 \\
Myalgia & 0.439 & 0.0001 \\
Laboratory parameters & & \\
Limphocyte count & -0.504 & 0.0001 \\
Platelet count & -0.492 & 0.0001 \\
Elevated D-Dimer $(>0.5 \mathrm{mg} / \mathrm{l})$ & 1.076 & 0.0001 \\
\hline
\end{tabular}

Fig. 4, panel F; adj.r $=0.161 ; p<0.0001$ after the adjustment for age).

\section{Discussion}

Applying a meta-analytic approach, we systematically reviewed and analyzed all predisposing clinical and biochemical features contributing to COVID-19-associated mortality. Our data show that associated morbidities are tightly related to an increased mortality in an age- and gender-dependent manner. Among clinical symptoms, dyspnea, fatigue and myalgia, along with respiratory rate, were the best predictors of MR, even after the adjustment for confounding factors. Finally, reduced lymphocyte and platelet count, along with increased D-dimer levels, all contribute to an overall increased mortality.

A large body of evidence has clearly documented that associated morbidities represented the most important factors related to higher MR in SARS-CoV-2 infected subjects [121]. Our data indicate that, after adjusting for confounders, DM is the best predictor of a worse COVID-19-related outcome. Interestingly, despite what observed in the whole population, the increased DM-related MR was independent to gender and attenuated in older patients. A previous metaanalysis including 6452 patients from 30 studies showed that DM was associated with a two-fold increased risk of poor outcome and mortality on COVID-19 subjects [122]. Similar data were more recently reported in a meta-analysis including 15 studies with SARS-CoV2 infection [123]. In line with these data, the Coronavirus SARS-CoV-2 and Diabetes Outcomes (CORONADO) study-a nationwide French multicenter, observational study, aimed at identifying the clinical and biological features associated with COVID19 outcomes in DM subjects-reported that hyperglycemia at admission worsened patient prognosis [124]. Similar observations have been previously reported for Severe Acute Respiratory Syndrome (SARS) and Middle East Respiratory Syndrome SARS [125] and MERS [126]. The specific underlying mechanisms related to the increased mortality rate observed in DM-SARS-CoV2 infected subjects are far to be elucidated. Several factors related to DM have been considered. People with diabetes are characterized by pulmonary dysfunction due to decreased lung volume, reduced pulmonary diffusing capacity, as well as ventilation control, bronchomotor tone and noradrenergic innervation impairment [127]. In addition, the diabetic population is more susceptible to infection, due to the associated lymphopenia and to the exaggerated inflammatory response associated with an increased renin-angiotensin system (RAS) activation in several tissues [128]. Finally, the increased $\mathrm{CV}$ risk associated with DM, as well as with hypertension, can further contribute to a poor COVID-19 prognosis. A large population-based study including 264,390 subjects with type $1 \mathrm{DM}$ and 2,874,020 patients with type $2 \mathrm{DM}$ registered with a general practice in England showed that DM COVID-19-related mortality was higher in males and directly associated with age, $\mathrm{CV}$ and renal complications as well as with poorer glycemic control and higher BMI [10]. Data derived from the present meta-analysis are in line with the latter findings. Older age and larger proportion of associated morbidities such as arterial hypertension and CKD within the whole population studied attenuated the DM-related risk. In addition, the inverse relationship with dyspnea severity at hospital admission suggests that DM plays a major role in worsening milder forms of COVID19 , whereas its contribution is less evident in more severe cases. Accordingly, the DM-related mortality risk is higher in those studies including patients with a higher lymphocyte count. Information on the role of DM treatment at enrolment or during hospitalization were not available in the present meta-analysis. However, it is important to recognize that both the glycometabolic control and the type of drug used for DM treatment have been considered as crucial factors related to DM outcome in COVID-19 [129-131]. The DM-related impaired immunological function is another factor can be considered. However, Lampasona et al. [132], using a highly specific and sensitive measurement of antibody immunoassays, reported a normal humoral response against SARS-CoV2 in DM subjects with COVID-19. 


\section{Study name}

\section{Statistics for each study}

Odds Lower Upper

ratio limit limit $p$-Value

$\begin{array}{lrrrr}\text { Abrishami A et al., 2020 } & 0,38 & 0,04 & 3,77 & 0,41 \\ \text { Arshad S et al., 2020 } & 0,98 & 0,79 & 1,21 & 0,82 \\ \text { Campochiaro et al., 2020 } & 2,00 & 0,16 & 24,33 & 0,59 \\ \text { Chilimuri S et al., 2020 } & 1,97 & 1,30 & 2,98 & 0,00 \\ \text { Chung MS et al., 2020 } & 16,67 & 1,86 & 149,66 & 0,01 \\ \text { Du RH et al., 2020 } & 1,94 & 0,69 & 5,45 & 0,21 \\ \text { Gao S et al., 2020 } & 1,74 & 0,74 & 4,10 & 0,20 \\ \text { Li L et al., 2020 } & 2,58 & 0,71 & 9,38 & 0,15 \\ \text { Pan F et al., 2020 } & 9,22 & 1,00 & 85,42 & 0,05 \\ \text { Ruan Q et al., 2020 } & 1,14 & 0,48 & 2,69 & 0,77 \\ \text { Smith AA et al., 2020 } & 1,96 & 1,25 & 3,08 & 0,00 \\ \text { Wang B et al., 2020 } & 1,07 & 0,28 & 4,06 & 0,92 \\ \text { Wang L et al., 2020 } & 1,09 & 0,53 & 2,26 & 0,81 \\ \text { Wang Y et al., 2020 } & 1,43 & 0,83 & 2,48 & 0,20 \\ \text { Xu J et al., 2020 } & 0,70 & 0,36 & 1,36 & 0,29 \\ \text { Xu PP et al., 2020 } & 6,79 & 3,16 & 14,57 & 0,00 \\ \text { Yang Q et al., 2020 } & 1,80 & 0,88 & 3,71 & 0,11 \\ \text { Ye W et al., 2020 } & 2,78 & 1,41 & 5,45 & 0,00 \\ \text { Yuan M et al., 2020 } & 50,56 & 2,38 & 1075,32 & 0,01 \\ \text { Zhou F et al., 2020 } & 2,85 & 1,35 & 6,05 & 0,01 \\ \text { Overall } & 1,85 & 1,36 & 2,51 & 0,00\end{array}$

\section{Odds ratio and $95 \%$ CI}

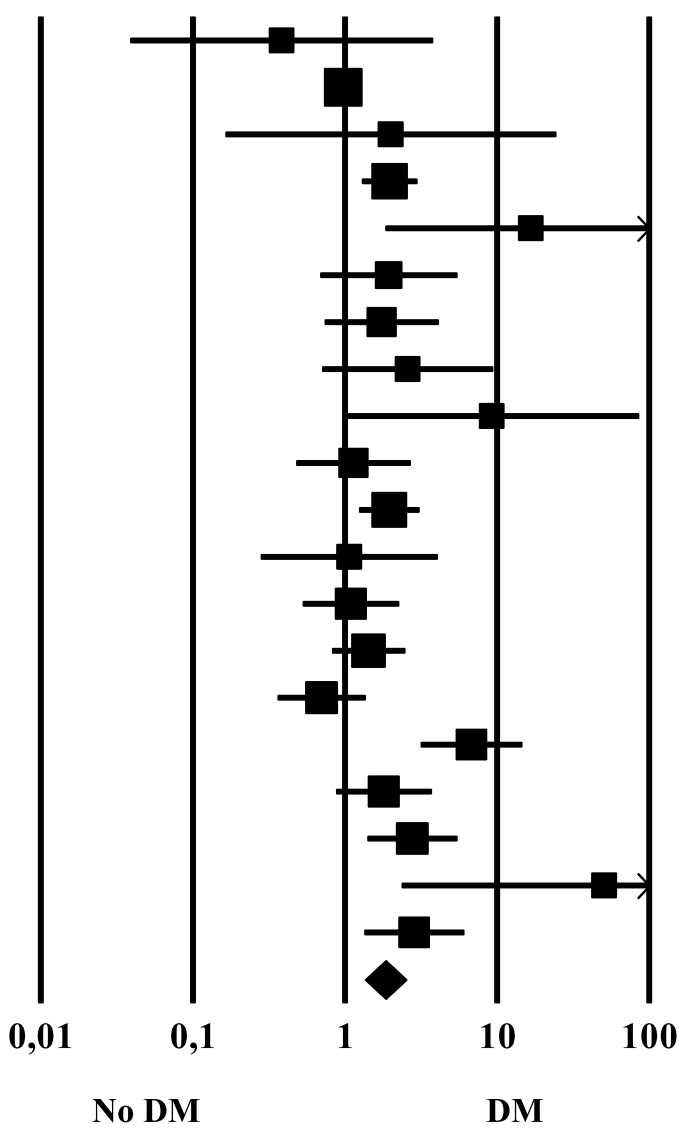

Fig. 4 Diabetes mellitus (DM)-related mortality rate. LLlower levels, UP upper levels

COPD was another independent risk factor associated with an increased mortality risk. A previous meta-analysis from China, considering only 11 case-series and 2002 subjects, showed that COPD was associated with a four-fold increased risk of mortality [133]. COPD is a chronic inflammatory condition of the large and, in particular, of the small airways, tightly related to smoking, characterized by lung parenchyma destruction, due to emphysema development and expiratory airflow limitation. The clinical presentation of COVID-19 infection can overlap with an acute exacerbation of COPD, resulting in a delay of correct clinical diagnosis and in a possible inappropriate medical intervention [121, 133]. Accordingly, a tight association between a higher MR and pulmonary symptoms, such as dyspnea and respiratory rate, was observed in the present study. All these factors can explain, at least partially, the worse outcomes observed in COPD patients.
Hypertension has been frequently reported as the most common associated morbidity in patients with COVID-19 [121].In addition, in line with what has been reported for other coronavirus infections_-such as SARS and MERShypertension has been considered as an independent risk factor for higher mortality and morbidity in patients with SARS-CoV-2 infection [121]. The specific underlying mechanisms linking hypertension and worse COVID-19 outcomes are far from having been elucidated. A mice model showed that SARS-CoV inoculation resulted in a down regulation of ACE2 cell expression [134]. The latter in turn can cause an excessive activation of RAS, possibly contributing to COVID-19-related lung injury progression, favoring an inflammatory response and a cytokine storm, stimulating the NADH/NADPH oxidase system [134]. In this context, the use of ACE inhibitors (ACEi) or of angiotensin II receptor blockers (ARBs) might be beneficial 

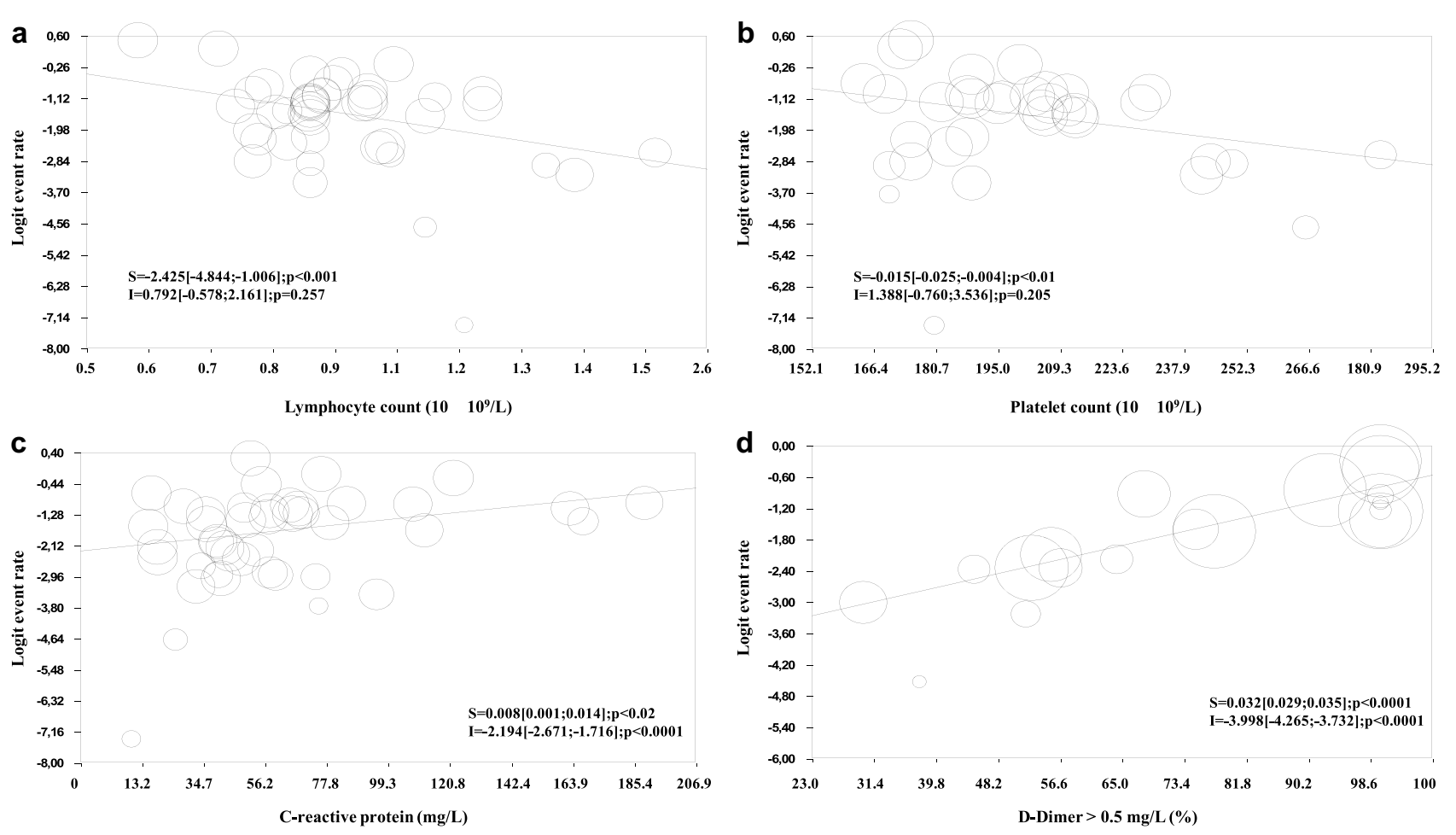

Fig. 5 Mortality rate according to different biochemical parameters: lymphocyte a or platelet $\mathbf{b}$ count, C-reactive protein c, pathological $(>0.5 \mathrm{mg} / \mathrm{L})$ D-dimer levels d

for COVID-19 outcomes [25, 85]. Although conflicting results were available on this issue $[135,136]$, a recent metaanalysis further supports a beneficial effect of ACEi and ARBs on disease progression [137].

Patients with active malignancies [138] and CKD [139] constitute a population enriched with frail people; hence, their association with a poor COVID-19 outcome is not surprising.

The association between male sex and higher MR deserves a more critical analysis. When compared to females, males are usually characterized by a higher prevalence of associated morbidities and higher CV risk, frequently related to risky behaviors, such as smoking, alcohol consumption, a diet enriched with fat and protein and reduced physical activity [140]. In addition, when compared to women, men generally consult health care services less frequently for preventive care [141]. This can result in symptom progression and a delay in a correct diagnosis, all factors which can contribute to a higher COVID-19 mortality. Another working hypothesis deals with the possibility that a different hormonal balance can contribute to the higher MR observed in men [13]. Accordingly, T can modulate transcriptionally or post-translationally the cell expression of ACE2 receptor and TMPRSS2, both crucial for SARS-CoV-2 cell internalization [13]. In addition, genotyping analysis has documented that a specific genetic variant in TMPRSS2 gene is totally absent in the East Asian population and more frequently observed in European and African American subjects $[142,143]$. In particular, this variant deals with different single nucleotide polymorphisms (SNPs) tightly associated with an androgen-dependent upregulation of TMPRSS2 expression [142, 143]. This observation can explain, at least partially, the lower MR observed in Asian populations. However, in preliminary studies, low $\mathrm{T}$, more than high $\mathrm{T}$, is associated with a higher COVID-19 lethality observed in men $[13,15,16]$. Accordingly, in a mouse model of influenza A virus lung infection, high androgens were associated with a more favorable pulmonary environment, promoting downregulation of detrimental inflammatory immune responses to protect against prolonged influenza disease [144]. Finally, low $\mathrm{T}$ is often associated with metabolic and cardiovascular derangements that could facilitate COVID-19 lethality [23, 24, 145]. Accordingly, a large placebo controlled trial showed that testosterone treatment in hypogonadal patients with impaired glucose tolerance of newly diagnosed type 2 DM (T2DM) reduced the proportion of diabetes at two years of follow up, beyond the effects of a lifestyle program [146]. Hence, variation in androgen milieu cannot completely explain the observed gender-related difference in MR. It is interesting to note that the positive relationship between male sex and lethality retains significance even after adjustment for associated comorbidities. In line with the latter hypothesis, gender was not related to DM-increased risk of mortality in the present meta-analysis.

An original finding of this study is the evaluation of the impact of clinical laboratory parameters on overall MR. Our study showed that reduced lymphocyte and platelet count, along 
with increased D-dimer levels, were the best predictors of an overall increased mortality. Among the latter factors, D-dimer is the best predictor of overall mortality. Emerging evidence has documented that, besides deep venous thrombosis (DVT), elevated D-dimer in COVID-19 patients can be the expression of capillary microthrombi, due to pulmonary capillary endothelial injury, which can contribute to the increased risk of death [147]. A recent study, performed in 184 COVID-19 patients, concluded that pulmonary embolism (PE) was the most frequent thrombotic complication (81\%) and that both age and coagulopathy were independent predictors of thrombotic complications [148]. Similar results were reported by other authors [149]. In line with the latter findings, a multicenter randomized controlled trial, comparing efficacy and safety of high- versus low-molecular weight heparin dosages in hospitalized patients with severe COVID-19 pneumonia and coagulopathy, is ongoing [150]. Reduced platelet count and lymphopenia, along with eosinopenia, have all been associated in these patients with more severe pneumonia and with higher inflammatory response [111]; hence, their association with higher mortality is not surprising. Similarly, symptoms such as myalgia and fatigue can be considered the expression of a more severe systemic inflammatory involvement, explaining their association with higher mortality risk.

Several limitations should be recognized. The vast majority of the meta-analyzed data derive from retrospective case series of hospitalized patients. Much evidence has clearly documented that in observational studies the completeness of follow-up and the management of missing data is crucial and a possible source of potential bias. Accordingly, a higher heterogeneity and publication bias was documented in the current study. A further limitation deals with the fact that estimating reproduction numbers for SARS-CoV-2 presents challenges due to the high proportion of infections not correctly detected by health systems, due to paucity, or even the lack, of symptoms and to changes in testing policies, thus resulting in different proportions of infections being detected over time and between countries. Hence, the reproducibility of our data warrants caution. In addition, the worldwide course of COVID-19 presents important temporal differences in line with the SARS-CoV-2 infection diffusion [151]. Hence, comparing data from different countries can constitute a further risk of bias. Finally, data on glycometabolic control and glucose variability, as well as the impact of diabetic treatment on COVID-19 outcomes, are limited, thus preventing definitive conclusions.

In conclusion, associated morbidities, and mostly diabetes mellitus, play a crucial role in COVID-19 hospitalized patient mortality. Specific biochemical parameters such as reduced lymphocyte and platelet count, as well as increased D-Dimer levels, represent other important risk factors. All physicians dealing with SARS-CoV-2 infected subjects should be aware of the underlying risk factor for poor prognosis. The optimization of glucose profile along with an adequate thrombotic complications preventive strategy must be become routine practice along with respiratory support and specific treatment, particularly in men. The specific reasons supporting the observed increased mortality in men have yet to be fully elucidated.

Supplementary Information The online version contains supplementary material available at https://doi.org/10.1007/s11154-021-09630-8.

Data Availability The complete dataset used for statistical analysis will be available to the Editorial Office, uploaded as Supplementary Material to the present Manuscript file.Declarations.

\section{Declarations}

Conflict of interest All authors declare that they don't have any financial interest neither they received support from institutions or companies mentioned in the present manuscript.

\section{References}

1. Zhou F, Yu T, Du R, Fan G, Liu Y, Liu Z, et al. Clinical course and risk factors for mortality of adult inpatients with COVID19 in Wuhan, China: a retrospective cohort study. Lancet. 2020;395(10229):1054-62. https://doi.org/10.1016/s01406736(20)30566-3.

2. Corona G, Baldi E, Isidori AM, Paoli D, Pallotti F, De Santis L, et al. SARS-CoV-2 infection, male fertility and sperm cryopreservation: a position statement of the Italian Society of Andrology and Sexual Medicine (SIAMS) (Società Italiana di Andrologia e Medicina della Sessualità). J Endocrinol Invest. 2020;43(8):1153-7. https://doi.org/10.1007/s40618-020-01290-w.

3. Huang C, Wang Y, Li X, Ren L, Zhao J, Hu Y, et al. Clinical features of patients infected with 2019 novel coronavirus in Wuhan. China Lancet. 2020;395(10223):497-506. https://doi. org/10.1016/s0140-6736(20)30183-5.

4. Phelan AL, Katz R, Gostin LO. The Novel Coronavirus Originating in Wuhan, China: Challenges for Global Health Governance. JAMA. 2020;323(8):709-10. https://doi. org/10.1001/jama.2020.1097.

5. Guo W, Li M, Dong Y, Zhou H, Zhang Z, Tian C et al. Diabetes is a risk factor for the progression and prognosis of COVID-19. Diabetes Metab Res Rev. 2020:e3319. https://doi.org/10.1002/ dmrr.3319.

6. Zhu L, She ZG, Cheng X, Qin JJ, Zhang XJ, Cai J, et al. Association of Blood Glucose Control and Outcomes in Patients with COVID19 and Pre-existing Type 2 Diabetes. Cell Metab. 2020;31(6):106877.e3. https://doi.org/10.1016/j.cmet.2020.04.021.

7. Erener S. Diabetes, infection risk and COVID-19. Mol Metab. 2020;39:101044. https://doi.org/10.1016/j.molmet.2020.101044.

8. Fleming N, Sacks LJ, Pham C, Neoh SL, Ekinci E. An overview of COVID-19 in people with diabetes pathophysiology and considerations in the inpatient setting. Diabet Med. 2020:e14509. https://doi.org/10.1111/dme.14509.

9. Wang S, Ma P, Zhang S, Song S, Wang Z, Ma Y, et al. Fasting blood glucose at admission is an independent predictor for 28-day mortality in patients with COVID-19 without previous diagnosis of diabetes: a multi-centre retrospective study. Diabetologia. 2020;63(10):2102-11. https://doi.org/10.1007/ s00125-020-05209-1. 
10. Holman N, Knighton P, Kar P, O’Keefe J, Curley M, Weaver A, et al. Risk factors for COVID-19-related mortality in people with type 1 and type 2 diabetes in England: a population-based cohort study. Lancet Diabetes Endocrinol. 2020;8(10):823-33. https:// doi.org/10.1016/s2213-8587(20)30271-0.

11. Loke YK, Golder SP, Vandenbroucke JP. Comprehensive evaluations of the adverse effects of drugs: importance of appropriate study selection and data sources. Ther Adv Drug Saf. 2011;2(2):59-68. https://doi.org/10.1177/2042098611401129.

12. Green MS, Swartz N, Nitzan D, Peer V. The male excess in case-fatality rates for COVID-19. A meta-analytic study of the age-related differences and consistency over six countries. medRxiv. 2020:2020.06.11.20128439. https://doi. org/10.1101/2020.06.11.20128439.

13. Pivonello R AR, Pivonello C, Millar RP, Isidori AM, Corona G, Colao A. 2020 Sexual disparities in covid-19 outcome: are men weaker or women stronger? . Neroendocrinology. 2020;In press

14. Salonia A, Corona G, Giwercman A, Maggi M, Minhas S, Nappi RE, et al. SARS-CoV-2, testosterone and frailty in males (PROTEGGIMI): A multidimensional research project. Andrology. 2020. https://doi.org/10.1111/andr.12811.

15. Rastrelli G, Di Stasi V, Inglese F, Beccaria M, Garuti M, Di Costanzo D, et al. Low testosterone levels predict clinical adverse outcomes in SARS-CoV-2 pneumonia patients. Andrology. 2020. https://doi.org/10.1111/andr.12821.

16. Çayan S, Uğuz M, Saylam B, Akbay E. Effect of serum total testosterone and its relationship with other laboratory parameters on the prognosis of coronavirus disease, 2019 (COVID-19) in SARS-CoV-2 infected male patients: a cohort study. Aging Male. 2020;1-11. https://doi.org/10.1080/13685538.2020.1807930.

17. Maseroli E, Corona G, Rastrelli G, Lotti F, Cipriani S, Forti $\mathrm{G}$, et al. Prevalence of endocrine and metabolic disorders in subjects with erectile dysfunction: a comparative study. J Sex Med. 2015;12(4):956-65. https://doi.org/10.1111/jsm.12832.

18. Grossmann M, Ng Tang Fui M, Cheung AS. Late-onset hypogonadism: metabolic impact. Andrology. 2019. https://doi. org/10.1111/andr.12705.

19. Grossmann M. Low testosterone in men with type 2 diabetes: significance and treatment. J Clin Endocrinol Metab. 2011;96(8):2341-53. https://doi.org/10.1210/jc.2011-0118.

20. Corona G, Mannucci E, Forti G, Maggi M. Following the common association between testosterone deficiency and diabetes mellitus, can testosterone be regarded as a new therapy for diabetes? Int J Androl. 2009;32(5):431-41. https://doi.org/ 10.1111/j.1365-2605.2009.00965.x.

21. Corona G, Vignozzi L, Sforza A, Maggi M. Risks and benefits of late onset hypogonadism treatment: an expert opinion. World J Mens Health. 2013;31(2):103-25. https://doi.org/10.5534/ wjmh.2013.31.2.103.

22. Corona G, Rastrelli G, Di Pasquale G, Sforza A, Mannucci E, Maggi M. Endogenous Testosterone Levels and Cardiovascular Risk: Meta-Analysis of Observational Studies. J Sex Med. 2018;15(9):1260-71. https://doi.org/10.1016/j.jsxm.2018.06.012.

23. Corona G, Maseroli E, Rastrelli G, Francomano D, Aversa A, Hackett GI, et al. Is late-onset hypogonadotropic hypogonadism a specific age-dependent disease, or merely an epiphenomenon caused by accumulating disease-burden? Minerva Endocrinol. 2016;41(2):196-210.

24. Turner HE, Wass JA. Gonadal function in men with chronic illness. Clin Endocrinol (Oxf). 1997;47(4):379-403. https://doi. org/10.1046/j.1365-2265.1997.2611108.x.

25. Shultz JM, Perlin A, Saltzman RG, Espinel Z, Galea S. Pandemic March: 2019 Coronavirus Disease's First Wave Circumnavigates the Globe. Disaster Med Public Health Prep. 2020:1-5. https:// doi.org/10.1017/dmp.2020.103
26. Li J, Huang DQ, Zou B, Yang H, Hui WZ, Rui F, et al. Epidemiology of COVID-19: A systematic review and meta-analysis of clinical characteristics, risk factors, and outcomes. J Med Virol. 2020. https://doi.org/10.1002/jmv.26424.

27. Wu X, Liu L, Jiao J, Yang L, Zhu B, Li X. Characterisation of clinical, laboratory and imaging factors related to mild vs. severe covid19 infection: a systematic review and meta-analysis. Ann Med. 2020;52(7):334-44. https://doi.org/10.1080/07853890.2020.1802061.

28. Qiu P, Zhou Y, Wang F, Wang H, Zhang M, Pan X, et al. Clinical characteristics, laboratory outcome characteristics, comorbidities, and complications of related COVID-19 deceased: a systematic review and meta-analysis. Aging Clin Exp Res. 2020;32(9):186978. https://doi.org/10.1007/s40520-020-01664-3.

29. Fang X, Li S, Yu H, Wang P, Zhang Y, Chen Z, et al. Epidemiological, comorbidity factors with severity and prognosis of COVID19: a systematic review and meta-analysis. Aging (Albany NY). 2020;12(13):12493-503. https://doi.org/10.18632/aging.103579.

30. Ahmed A, Ali A, Hasan S. Comparison of Epidemiological Variations in COVID-19 Patients Inside and Outside of ChinaA Meta-Analysis. Front Public Health. 2020;8:193. https://doi. org/10.3389/fpubh.2020.00193.

31. Nasiri MJ, Haddadi S, Tahvildari A, Farsi Y, Arbabi M, Hasanzadeh S, et al. COVID-19 Clinical Characteristics, and Sex-Specific Risk of Mortality: Systematic Review and Meta-Analysis. Front Med (Lausanne). 2020;7:459. https://doi.org/10.3389/fmed.2020.00459.

32. Parohan M, Yaghoubi S, Seraji A, Javanbakht MH, Sarraf P, Djalali M. Risk factors for mortality in patients with Coronavirus disease 2019 (COVID-19) infection: a systematic review and meta-analysis of observational studies. Aging Male. 2020:1-9. https://doi.org/10.1080/13685538.2020.1774748.

33. Jutzeler CR, Bourguignon L, Weis CV, Tong B, Wong C, Rieck B, et al. Comorbidities, clinical signs and symptoms, laboratory findings, imaging features, treatment strategies, and outcomes in adult and pediatric patients with COVID-19: A systematic review and meta-analysis. Travel Med Infect Dis. 2020;37:101825. https://doi.org/10.1016/j.tmaid.2020.101825.

34. Ssentongo P, Ssentongo AE, Heilbrunn ES, Ba DM, Chinchilli VM. Association of cardiovascular disease and 10 other preexisting comorbidities with COVID-19 mortality: A systematic review and meta-analysis. PLoS ONE. 2020;15(8):e0238215. https://doi.org/10.1371/journal.pone.0238215.

35. Abrishami A, Khalili N, Dalili N, Khaleghnejad Tabari R, Farjad R, Samavat S, et al. Clinical and Radiologic Characteristics of COVID19 in Patients With CKD. Iran J Kidney Dis. 2020;14(4):267-77.

36. Aggarwal S, Garcia-Telles N, Aggarwal G, Lavie C, Lippi G, Henry BM. Clinical features, laboratory characteristics, and outcomes of patients hospitalized with coronavirus disease 2019 (COVID-19): Early report from the United States. Diagnosis (Berl). 2020;7(2):91-6. https://doi.org/10.1515/dx-2020-0046.

37. Alberici F, Delbarba E, Manenti C, Econimo L, Valerio F, Pola A, et al. A single center observational study of the clinical characteristics and short-term outcome of 20 kidney transplant patients admitted for SARS-CoV2 pneumonia. Kidney Int. 2020;97(6):1083-8. https://doi.org/10.1016/j.kint.2020.04.002.

38. Argenziano MG, Bruce SL, Slater CL, Tiao JR, Baldwin MR, Barr RG, et al. Characterization and clinical course of 1000 patients with coronavirus disease 2019 in New York: retrospective case series. BMJ. 2020;369:m1996. https://doi. org/10.1136/bmj.m1996.

39. Arshad S, Kilgore P, Chaudhry ZS, Jacobsen G, Wang DD, Huitsing $\mathrm{K}$, et al. Treatment with hydroxychloroquine, azithromycin, and combination in patients hospitalized with COVID-19. Int J Infect Dis. 2020;97:396-403. https://doi. org/10.1016/j.ijid.2020.06.099. 
40. Bezzio C, Saibeni S, Variola A, Allocca M, Massari A, Gerardi $\mathrm{V}$, et al. Outcomes of COVID-19 in 79 patients with IBD in Italy: an IG-IBD study. Gut. 2020;69(7):1213-7. https://doi. org/10.1136/gutjnl-2020-321411.

41. Borba MGS, Val FFA, Sampaio VS, Alexandre MAA, Melo GC, Brito $\mathrm{M}$ et al. Effect of High vs Low Doses of Chloroquine Diphosphate as Adjunctive Therapy for Patients Hospitalized With Severe Acute Respiratory Syndrome Coronavirus 2 (SARS-CoV-2) Infection: A Randomized Clinical Trial. JAMA Netw Open. 27020;3(4):e208857. https://doi.org/10.1001/jamanetworkopen.2020.8857.

42. Burns GP, Lane ND, Tedd HM, Deutsch E, Douglas F, West $\mathrm{SD}$ et al. Improved survival following ward-based non-invasive pressure support for severe hypoxia in a cohort of frail patients with COVID-19: retrospective analysis from a UK teaching hospital. BMJ Open Respir Res. 2020;7(1). https://doi.org/10.1136/bmjresp2020-000621.

43. Campochiaro C, Della-Torre E, Cavalli G, De Luca G, Ripa M, Boffini $\mathrm{N}$, et al. Efficacy and safety of tocilizumab in severe COVID-19 patients: a single-centre retrospective cohort study. Eur J Intern Med. 2020;76:43-9. https://doi.org/10.1016/j.ejim.2020.05.021.

44. Cao B, Wang Y, Wen D, Liu W, Wang J, Fan G, et al. A Trial of Lopinavir-Ritonavir in Adults Hospitalized with Severe Covid-19. N Engl J Med. 2020;382(19):1787-99. https://doi.org/10.1056/ NEJMoa2001282.

45. Capra R, De Rossi N, Mattioli F, Romanelli G, Scarpazza C, Sormani MP, et al. Impact of low dose tocilizumab on mortality rate in patients with COVID-19 related pneumonia. Eur J Intern Med. 2020;76:31-5. https://doi.org/10.1016/j.ejim.2020.05.009.

46. Cheng Y, Luo R, Wang K, Zhang M, Wang Z, Dong L, et al. Kidney disease is associated with in-hospital death of patients with COVID-19. Kidney Int. 2020;97(5):829-38. https://doi. org/10.1016/j.kint.2020.03.005.

47. Chilimuri S, Sun H, Alemam A, Mantri N, Shehi E, Tejada J, et al. Predictors of Mortality in Adults Admitted with COVID-19: Retrospective Cohort Study from New York City. West J Emerg Med. 2020;21(4):779-84. https://doi.org/10.5811/westjem. 2020.6.47919.

48. Chung SM, Lee YY, Ha E, Yoon JS, Won KC, Lee HW, et al. The Risk of Diabetes on Clinical Outcomes in Patients with Coronavirus Disease 2019: A Retrospective Cohort Study. Diabetes Metab J. 2020;44(3):405-13. https://doi.org/10.4093/ dmj.2020.0105.

49. Cui X, Yu X, Wu X, Huang L, Tian Y, Huang X, et al. Acute Kidney Injury in Patients with the Coronavirus Disease 2019: A Multicenter Study. Kidney Blood Press Res. 2020;45(4):612-22. https://doi.org/10.1159/000509517.

50. De Smet R, Mellaerts B, Vandewinckele H, Lybeert P, Frans E, Ombelet $\mathrm{S}$ et al. Frailty and Mortality in Hospitalized Older Adults With COVID-19: Retrospective Observational Study. J Am Med Dir Assoc. 2020;21(7):928-32 e1. https://doi.org/10.1016/j. jamda.2020.06.008.

51. Du RH, Liang LR, Yang CQ, Wang W, Cao TZ, Li M et al. Predictors of mortality for patients with COVID-19 pneumonia caused by SARS-CoV-2: a prospective cohort study. Eur Respir J. 2020;55(5). https://doi.org/10.1183/13993003.00524-2020.

52. Feng Y, Ling Y, Bai T, Xie Y, Huang J, Li J, et al. COVID19 with Different Severities: A Multicenter Study of Clinical Features. Am J Respir Crit Care Med. 2020;201(11):1380-8. https://doi.org/10.1164/rccm.202002-0445OC.

53. Gao L, Jiang D, Wen XS, Cheng XC, Sun M, He B, et al. Prognostic value of NT-proBNP in patients with severe COVID-19. Respir Res. 2020;21(1):83. https://doi.org/10.1186/ s12931-020-01352-w.

54. Gregoriano C, Koch D, Haubitz S, Conen A, Fux CA, Mueller $\mathrm{B}$, et al. Characteristics, predictors and outcomes among 99 patients hospitalised with COVID-19 in a tertiary care centre in Switzerland: an observational analysis. Swiss Med Wkly. 2020;150:w20316. https://doi.org/10.4414/smw.2020.20316.

55. Grein J, Ohmagari N, Shin D, Diaz G, Asperges E, Castagna A, et al. Compassionate Use of Remdesivir for Patients with Severe Covid-19. N Engl J Med. 2020;382(24):2327-36. https://doi. org/10.1056/NEJMoa2007016.

56. Hong KS, Lee KH, Chung JH, Shin KC, Choi EY, Jin HJ, et al. Clinical Features and Outcomes of 98 Patients Hospitalized with SARS-CoV-2 Infection in Daegu, South Korea: A Brief Descriptive Study. Yonsei Med J. 2020;61(5):431-7. https:// doi.org/10.3349/ymj.2020.61.5.431.

57. Huang M, Yang Y, Shang F, Zheng Y, Zhao W, Luo L, et al. Clinical Characteristics and Predictors of Disease Progression in Severe Patients with COVID-19 Infection in Jiangsu Province, China: A Descriptive Study. Am J Med Sci. 2020;360(2):120-8. https://doi.org/10.1016/j.amjms.2020.05.038.

58. Inciardi RM, Adamo M, Lupi L, Cani DS, Di Pasquale M, Tomasoni D, et al. Characteristics and outcomes of patients hospitalized for COVID-19 and cardiac disease in Northern Italy. Eur Heart J. 2020;41(19):1821-9. https://doi.org/10.1093/ eurheartj/ehaa388.

59. Israelsen SB, Kristiansen KT, Hindsberger B, Ulrik CS, Andersen O, Jensen $\mathrm{M}$ et al. Characteristics of patients with COVID-19 pneumonia at Hvidovre Hospital, March-April 2020. Dan Med J. 2020;67(6).

60. Itelman E, Wasserstrum Y, Segev A, Avaky C, Negru L, Cohen D, et al. Clinical Characterization of 162 COVID-19 patients in Israel: Preliminary Report from a Large Tertiary Center. Isr Med Assoc J. 2020;22(5):271-4.

61. Jang JG, Hur J, Hong KS, Lee W, Ahn JH. Prognostic Accuracy of the SIRS, qSOFA, and NEWS for Early Detection of Clinical Deterioration in SARS-CoV-2 Infected Patients. J Korean Med Sci. 2020;35(25):e234. https://doi.org/10.3346/jkms.2020.35.e234.

62. Lagi F, Piccica M, Graziani L, Vellere I, Botta A, Tilli M et al. Early experience of an infectious and tropical diseases unit during the coronavirus disease (COVID-19) pandemic, Florence, Italy, February to March 2020. Euro Surveill. 2020;25(17). https://doi. org/10.2807/1560-7917.ES.2020.25.17.2000556.

63. Lecronier M, Beurton A, Burrel S, Haudebourg L, Deleris R, Le Marec J, et al. Comparison of hydroxychloroquine, lopinavir/ritonavir, and standard of care in critically ill patients with SARS-CoV-2 pneumonia: an opportunistic retrospective analysis. Crit Care. 2020;24(1):418. https://doi.org/10.1186/s13054-020-03117-9.

64. Lewnard JA, Liu VX, Jackson ML, Schmidt MA, Jewell BL, Flores JP, et al. Incidence, clinical outcomes, and transmission dynamics of severe coronavirus disease 2019 in California and Washington: prospective cohort study. BMJ. 2020;369:m1923. https://doi.org/10.1136/bmj.m1923.

65. Li L, Yang L, Gui S, Pan F, Ye T, Liang B, et al. Association of clinical and radiographic findings with the outcomes of 93 patients with COVID-19 in Wuhan. China Theranostics. 2020;10(14):6113-21. https://doi.org/10.7150/thno.46569.

66. Li R, Tian J, Yang F, Lv L, Yu J, Sun G, et al. Clinical characteristics of 225 patients with COVID-19 in a tertiary Hospital near Wuhan. China J Clin Virol. 2020;127:104363. https://doi.org/10.1016/j. jcv.2020.104363.

67. Li X, Guo Z, Li B, Zhang X, Tian R, Wu W, et al. Extracorporeal Membrane Oxygenation for Coronavirus Disease 2019 in Shanghai. China ASAIO J. 2020;66(5):475-81. https://doi. org/10.1097/MAT.0000000000001172.

68. Liu X, Zheng X, Liu B, Wu M, Zhang Z, Zhang G, et al. Serum IgM against SARS-CoV-2 correlates with in-hospital mortality in severe/critical patients with COVID-19 in Wuhan. China Aging (Albany NY). 2020;12(13):12432-40. https://doi.org/10.18632/ aging.103417. 
69. McMichael TM, Currie DW, Clark S, Pogosjans S, Kay M, Schwartz NG, et al. Epidemiology of Covid-19 in a LongTerm Care Facility in King County. Washington N Engl J Med. 2020;382(21):2005-11. https://doi.org/10.1056/NEJMoa2005412.

70. Meng Y, Wu P, Lu W, Liu K, Ma K, Huang L, et al. Sex-specific clinical characteristics and prognosis of coronavirus disease-19 infection in Wuhan, China: A retrospective study of 168 severe patients. PLoS Pathog. 2020;16(4):e1008520. https://doi. org/10.1371/journal.ppat.1008520.

71. Miyashita S, Yamada T, Mikami T, Miyashita H, Chopra N, Rizk D. Impact of dementia on clinical outcomes in elderly patients with coronavirus 2019 (COVID-19): an experience in New York. Geriatr Gerontol Int. 2020;20(7):732-4. https://doi.org/10.1111/ggi.13942.

72. Moghaddam A, Heller RA, Sun Q, Seelig J, Cherkezov A, Seibert L et al. Selenium Deficiency Is Associated with Mortality Risk from COVID-19. Nutrients. 2020;12(7). https://doi.org/10.3390/ nu12072098.

73. Morena V, Milazzo L, Oreni L, Bestetti G, Fossali T, Bassoli C, et al. Off-label use of tocilizumab for the treatment of SARSCoV-2 pneumonia in Milan. Italy Eur J Intern Med. 2020;76:3642. https://doi.org/10.1016/j.ejim.2020.05.011.

74. Myrstad M, Ihle-Hansen H, Tveita AA, Andersen EL, Nygard S, Tveit A, et al. National Early Warning Score 2 (NEWS2) on admission predicts severe disease and in-hospital mortality from Covid-19 a prospective cohort study. Scand J Trauma Resusc Emerg Med. 2020;28(1):66. https://doi.org/10.1186/s13049-020-00764-3.

75. Na KR, Kim HR, Ham Y, Choi DE, Lee KW, Moon JY, et al. Acute Kidney Injury and Kidney Damage in COVID-19 Patients. J Korean Med Sci. 2020;35(28):e257. https://doi.org/10.3346/ jkms.2020.35.e257.

76. Nightingale R, Nwosu N, Kutubudin F, Fletcher T, Lewis J, Frost $\mathrm{F}$ et al. Is continuous positive airway pressure (CPAP) a new standard of care for type 1 respiratory failure in COVID19 patients? A retrospective observational study of a dedicated COVID-19 CPAP service. BMJ Open Respir Res. 2020;7(1). https://doi.org/10.1136/bmjresp-2020-000639.

77. Nikpouraghdam M, Jalali Farahani A, Alishiri G, Heydari S, Ebrahimnia M, Samadinia H, et al. Epidemiological characteristics of coronavirus disease 2019 (COVID-19) patients in IRAN: A single center study. J Clin Virol. 2020;127:104378. https://doi. org/10.1016/j.jcv.2020.104378.

78. Nowak B, Szymanski P, Pankowski I, Szarowska A, Zycinska $\mathrm{K}$, Rogowski W, et al. Clinical characteristics and shortterm outcomes of patients with coronavirus disease 2019: a retrospective single-center experience of a designated hospital in Poland. Pol Arch Intern Med. 2020;130(5):407-11. https://doi. org/10.20452/pamw.15361.

79. Pan F, Zheng C, Ye T, Li L, Liu D, Li L, et al. Different computed tomography patterns of Coronavirus Disease 2019 (COVID-19) between survivors and non-survivors. Sci Rep. 2020;10(1):11336. https://doi.org/10.1038/s41598-020-68057-4.

80. Pei G, Zhang Z, Peng J, Liu L, Zhang C, Yu C, et al. Renal Involvement and Early Prognosis in Patients with COVID-19 Pneumonia. J Am Soc Nephrol. 2020;31(6):1157-65. https://doi. org/10.1681/ASN.2020030276.

81. Pellaud C, Grandmaison G, Pham Huu Thien HP, Baumberger M, Carrel G, Ksouri $\mathrm{H}$ et al. Characteristics, comorbidities, 30-day outcome and in-hospital mortality of patients hospitalised with COVID-19 in a Swiss area - a retrospective cohort study. Swiss Med Wkly. 2020;150:w20314. https://doi.org/10.4414/ smw.2020.20314

82. Ren H, Yang Y, Wang F, Yan Y, Shi X, Dong K, et al. Association of the insulin resistance marker TyG index with the severity and mortality of COVID-19. Cardiovasc Diabetol. 2020;19(1):58. https://doi.org/10.1186/s12933-020-01035-2.
83. Ruan Q, Yang K, Wang W, Jiang L, Song J. Clinical predictors of mortality due to COVID-19 based on an analysis of data of 150 patients from Wuhan. China Intensive Care Med. 2020;46(5):846-8. https://doi.org/10.1007/s00134-020-05991-x.

84. Satlin MJ, Goyal P, Magleby R, Maldarelli GA, Pham K, Kondo M, et al. Safety, tolerability, and clinical outcomes of hydroxychloroquine for hospitalized patients with coronavirus 2019 disease. PLoS ONE. 2020;15(7):e0236778. https://doi. org/10.1371/journal.pone.0236778.

85. Senkal N, Meral R, Medetalibeyoglu A, Konyaoglu H, Kose M, Tukek T. Association between chronic ACE inhibitor exposure and decreased odds of severe disease in patients with COVID19. Anatol J Cardiol. 2020;24(1):21-9. https://doi.org/10.14744 /AnatolJCardiol.2020.57431.

86. Shao F, Xu S, Ma X, Xu Z, Lyu J, Ng M, et al. In-hospital cardiac arrest outcomes among patients with COVID-19 pneumonia in Wuhan. China Resuscitation. 2020;151:18-23. https://doi. org/10.1016/j.resuscitation.2020.04.005.

87. Shi Y, Yu X, Zhao H, Wang H, Zhao R, Sheng J. Host susceptibility to severe COVID-19 and establishment of a host risk score: findings of 487 cases outside Wuhan. Crit Care. 2020;24(1):108. https://doi.org/10.1186/s13054-020-2833-7.

88. Smith AA, Fridling J, Ibhrahim D, Porter PS Jr. Identifying Patients at Greatest Risk of Mortality due to COVID-19: A New England Perspective. West J Emerg Med. 2020;21(4):785-9. https://doi.org/10.5811/westjem.2020.6.47957.

89. Song JW, Zhang C, Fan X, Meng FP, Xu Z, Xia P, et al. Immunological and inflammatory profiles in mild and severe cases of COVID-19. Nat Commun. 2020;11(1):3410. https://doi. org/10.1038/s41467-020-17240-2.

90. Steinberg E, Wright E, Kushner B. In Young Adults with COVID-19, Obesity Is Associated with Adverse Outcomes. West J Emerg Med. 2020;21(4):752-5. https://doi.org/10.5811/ westjem.2020.5.47972.

91. Tang N, Li D, Wang X, Sun Z. Abnormal coagulation parameters are associated with poor prognosis in patients with novel coronavirus pneumonia. J Thromb Haemost. 2020;18(4):844-7. https://doi.org/10.1111/jth.14768.

92. Tharakan S, Nomoto K, Miyashita S, Ishikawa K. Body temperature correlates with mortality in COVID-19 patients. Crit Care. 2020;24(1):298. https://doi.org/10.1186/s13054-020-03045-8.

93. Trigo J, Garcia-Azorin D, Planchuelo-Gomez A, Martinez-Pias E, Talavera B, Hernandez-Perez I, et al. Factors associated with the presence of headache in hospitalized COVID-19 patients and impact on prognosis: a retrospective cohort study. J Headache Pain. 2020;21(1):94. https://doi.org/10.1186/s10194-020-01165-8.

94. Vuagnat P, Frelaut M, Ramtohul T, Basse C, Diakite S, Noret A, et al. COVID-19 in breast cancer patients: a cohort at the Institut Curie hospitals in the Paris area. Breast Cancer Res. 2020;22(1):55. https://doi.org/10.1186/s13058-020-01293-8.

95. Wang B, Van Oekelen O, Mouhieddine TH, Del Valle DM, Richter J, Cho HJ, et al. A tertiary center experience of multiple myeloma patients with COVID-19: lessons learned and the path forward. J Hematol Oncol. 2020;13(1):94. https://doi. org/10.1186/s13045-020-00934-X.

96. Wang L, He W, Yu X, Hu D, Bao M, Liu H, et al. Coronavirus disease 2019 in elderly patients: Characteristics and prognostic factors based on 4-week follow-up. J Infect. 2020;80(6):639-45. https://doi.org/10.1016/j.jinf.2020.03.019.

97. Wang L, Li X, Chen H, Yan S, Li D, Li Y, et al. Coronavirus Disease 19 Infection Does Not Result in Acute Kidney Injury: An Analysis of 116 Hospitalized Patients from Wuhan. China Am J Nephrol. 2020;51(5):343-8. https://doi.org/10.1159/000507471.

98. Wang Y, Lu X, Li Y, Chen H, Chen T, Su N, et al. Clinical Course and Outcomes of 344 Intensive Care Patients with COVID-19. 
Am J Respir Crit Care Med. 2020;201(11):1430-4. https://doi. org/10.1164/rccm.202003-0736LE.

99. Xie J, Covassin N, Fan Z, Singh P, Gao W, Li G, et al. Association Between Hypoxemia and Mortality in Patients With COVID-19. Mayo Clin Proc. 2020;95(6):1138-47. https://doi.org/10.1016/j. mayocp.2020.04.006.

100. Xu J, Yang X, Yang L, Zou X, Wang Y, Wu Y, et al. Clinical course and predictors of 60-day mortality in 239 critically ill patients with COVID-19: a multicenter retrospective study from Wuhan, China. Crit Care. 2020;24(1):394. https://doi.org/10.1186/ s13054-020-03098-9.

101. Xu PP, Tian RH, Luo S, Zu ZY, Fan B, Wang XM, et al. Risk factors for adverse clinical outcomes with COVID-19 in China: a multicenter, retrospective, observational study. Theranostics. 2020;10(14):6372-83. https://doi.org/10.7150/thno.46833.

102. Xu X, Han M, Li T, Sun W, Wang D, Fu B, et al. Effective treatment of severe COVID-19 patients with tocilizumab. Proc Natl Acad Sci U S A. 2020;117(20):10970-5. https://doi.org/10.1073/ pnas.2005615117.

103. Yan Y, Yang Y, Wang F, Ren H, Zhang S, Shi X et al. Clinical characteristics and outcomes of patients with severe covid-19 with diabetes. BMJ Open Diabetes Res Care. 2020;8(1). https:// doi.org/10.1136/bmjdrc-2020-001343.

104. Yang BY, Barnard LM, Emert JM, Drucker C, Schwarcz L, Counts $\mathrm{CR}$, et al. Clinical Characteristics of Patients With Coronavirus Disease 2019 (COVID-19) Receiving Emergency Medical Services in King County, Washington. JAMA Netw Open. 2020;3(7):e2014549. https://doi.org/10.1001/jamanetworkopen. 2020.14549.

105. Yang Q, Zhou Y, Wang X, Gao S, Xiao Y, Zhang W, et al. Effect of hypertension on outcomes of adult inpatients with COVID-19 in Wuhan, China: a propensity score-matching analysis. Respir Res. 2020;21(1):172. https://doi.org/10.1186/s12931-020-01435-8.

106. Yang X, Yang Q, Wang Y, Wu Y, Xu J, Yu Y, et al. Thrombocytopenia and its association with mortality in patients with COVID-19. J Thromb Haemost. 2020;18(6):1469-72. https://doi.org/10.1111/ jth.14848.

107. Ye W, Chen G, Li X, Lan X, Ji C, Hou M, et al. Dynamic changes of D-dimer and neutrophil-lymphocyte count ratio as prognostic biomarkers in COVID-19. Respir Res. 2020;21(1):169. https:// doi.org/10.1186/s12931-020-01428-7.

108. Yuan M, Yin W, Tao Z, Tan W, Hu Y. Association of radiologic findings with mortality of patients infected with 2019 novel coronavirus in Wuhan, China. PLoS ONE. 2020;15(3):e0230548. https://doi.org/10.1371/journal.pone.0230548.

109. Zhang G, Hu C, Luo L, Fang F, Chen Y, Li J, et al. Clinical features and short-term outcomes of 221 patients with COVID19 in Wuhan. China J Clin Virol. 2020;127:104364. https://doi. org/10.1016/j.jcv.2020.104364.

110. Zhang J, Wang X, Jia X, Li J, Hu K, Chen G, et al. Risk factors for disease severity, unimprovement, and mortality in COVID-19 patients in Wuhan. China Clin Microbiol Infect. 2020;26(6):76772. https://doi.org/10.1016/j.cmi.2020.04.012.

111. Zhang J, Meng G, Li W, Shi B, Dong H, Su Z, et al. Relationship of chest CT score with clinical characteristics of 108 patients hospitalized with COVID-19 in Wuhan, China. Respir Res. 2020;21(1):180. https://doi.org/10.1186/s12931-020-01440-x.

112. Zhang L, Yan X, Fan Q, Liu H, Liu X, Liu Z, et al. D-dimer levels on admission to predict in-hospital mortality in patients with Covid-19. J Thromb Haemost. 2020;18(6):1324-9. https:// doi.org/10.1111/jth.14859.

113. Zhang P, Zhu L, Cai J, Lei F, Qin JJ, Xie J, et al. Association of Inpatient Use of Angiotensin-Converting Enzyme Inhibitors and Angiotensin II Receptor Blockers With Mortality Among Patients With Hypertension Hospitalized With COVID-19. Circ Res.
2020;126(12):1671-81. https://doi.org/10.1161/CIRCRESAHA. 120.317134.

114. Zhang S, Guo M, Duan L, Wu F, Hu G, Wang Z, et al. Development and validation of a risk factor-based system to predict short-term survival in adult hospitalized patients with COVID-19: a multicenter, retrospective, cohort study. Crit Care. 2020;24(1):438. https://doi.org/10.1186/s13054-020-03123-x.

115. Zhang SY, Lian JS, Hu JH, Zhang XL, Lu YF, Cai H, et al. Clinical characteristics of different subtypes and risk factors for the severity of illness in patients with COVID-19 in Zhejiang, China. Infect Dis Poverty. 2020;9(1):85. https://doi.org/10.1186/ s40249-020-00710-6.

116. Zhao XY, Xu XX, Yin HS, Hu QM, Xiong T, Tang YY, et al. Clinical characteristics of patients with 2019 coronavirus disease in a non-Wuhan area of Hubei Province, China: a retrospective study. BMC Infect Dis. 2020;20(1):311. https://doi.org/10.1186/ s12879-020-05010-w.

117. Zhu L, Gong N, Liu B, Lu X, Chen D, Chen S, et al. Coronavirus Disease 2019 Pneumonia in Immunosuppressed Renal Transplant Recipients: A Summary of 10 Confirmed Cases in Wuhan. China Eur Urol. 2020;77(6):748-54. https://doi.org/10.1016/j.eururo. 2020.03.039.

118. Zou X, Li S, Fang M, Hu M, Bian Y, Ling J, et al. Acute Physiology and Chronic Health Evaluation II Score as a Predictor of Hospital Mortality in Patients of Coronavirus Disease 2019. Crit Care Med. 2020;48(8):e657-65. https://doi.org/10.1097/ ccm.0000000000004411.

119. Higgins JPT SJ, Savovi? J, Page MJ, Hróbjartsson A, Boutron I, Reeves B \& Eldridge S. A revised tool for assessing risk of bias in randomized trials. Cochrane Database of Systematic Reviews. Cochrane Methods. 2016.

120. Begg CB, Mazumdar M. Operating Characteristics of a Rank Correlation Test for Publication Bias. Biometrics. 1994;50(4):1088-101. https://doi.org/10.2307/2533446.

121. Sanyaolu A, Okorie C, Marinkovic A, Patidar R, Younis K, Desai $\mathrm{P}$ et al. Comorbidity and its Impact on Patients with COVID-19. SN Compr Clin Med. 2020:1-8. https://doi.org/10.1007/s42399020-00363-4.

122. Huang I, Lim MA, Pranata R. Diabetes mellitus is associated with increased mortality and severity of disease in COVID-19 pneumonia - A systematic review, meta-analysis, and metaregression. Diabetes Metab Syndr. 2020;14(4):395-403. https:// doi.org/10.1016/j.dsx.2020.04.018.

123. Mantovani A, Byrne CD, Zheng MH, Targher G. Diabetes as a risk factor for greater COVID-19 severity and in-hospital death: A meta-analysis of observational studies. Nutr Metab Cardiovasc Dis. 2020;30(8):1236-48. https://doi.org/10.1016/j.numecd.2020.05.014.

124. Cariou B, Hadjadj S, Wargny M, Pichelin M, Al-Salameh A, Allix I, et al. Phenotypic characteristics and prognosis of inpatients with COVID-19 and diabetes: the CORONADO study. Diabetologia. 2020;63(8):1500-15. https://doi.org/10.1007/ s00125-020-05180-x.

125. Booth CM, Matukas LM, Tomlinson GA, Rachlis AR, Rose DB, Dwosh HA, et al. Clinical features and short-term outcomes of 144 patients with SARS in the greater Toronto area. JAMA. 2003;289(21):2801-9. https://doi.org/10.1001/jama.289.21. JOC30885.

126. Alqahtani FY, Aleanizy FS, Ali El Hadi Mohamed R, Alanazi MS, Mohamed N, Alrasheed MM et al. Prevalence of comorbidities in cases of Middle East respiratory syndrome coronavirus: a retrospective study. Epidemiol Infect. 2018;147:15. https://doi.org/10.1017/s0950268818002923.

127. Fuso L, Pitocco D, Antonelli-Incalzi R. Diabetic lung, an underrated complication from restrictive functional pattern to pulmonary hypertension. Diabetes Metab Res Rev. 2019;35(6):e3159. https://doi.org/10.1002/dmrr.3159. 
128. Candido R, Jandeleit-Dahm KA, Cao Z, Nesteroff SP, Burns WC, Twigg SM, et al. Prevention of accelerated atherosclerosis by angiotensin-converting enzyme inhibition in diabetic apolipoprotein E-deficient mice. Circulation. 2002;106(2):24653. https://doi.org/10.1161/01.cir.0000021122.63813.32.

129. Bramante CT, Ingraham NE, Murray TA, Marmor S, Hovertsen $\mathrm{S}$, Gronski J, et al. Metformin and risk of mortality in patients hospitalised with COVID-19: a retrospective cohort analysis. The Lancet Healthy Longevity. 2020. https://doi.org/10.1016/ s2666-7568(20)30033-7.

130. Solerte SB, D’Addio F, Trevisan R, Lovati E, Rossi A, Pastore I, et al. Sitagliptin Treatment at the Time of Hospitalization Was Associated With Reduced Mortality in Patients With Type 2 Diabetes and COVID-19: A Multicenter, CaseControl, Retrospective. Observational Study Diabetes Care. 2020;43(12):2999-3006. https://doi.org/10.2337/dc20-1521.

131. Mirani M, Favacchio G, Carrone F, Betella N, Biamonte E, Morenghi E, et al. Impact of Comorbidities and Glycemia at Admission and Dipeptidyl Peptidase 4 Inhibitors in Patients With Type 2 Diabetes With COVID-19: A Case Series From an Academic Hospital in Lombardy. Italy Diabetes Care. 2020;43(12):3042-9. https://doi.org/10.2337/dc20-1340.

132. Lampasona V, Secchi M, Scavini M, Bazzigaluppi E, Brigatti C, Marzinotto I, et al. Antibody response to multiple antigens of SARS-CoV-2 in patients with diabetes: an observational cohort study. Diabetologia. 2020;63(12):2548-58. https://doi. org/10.1007/s00125-020-05284-4.

133. Zhao Q, Meng M, Kumar R, Wu Y, Huang J, Lian N, et al. The impact of COPD and smoking history on the severity of COVID19: A systemic review and meta-analysis. J Med Virol. 2020. https://doi.org/10.1002/jmv.25889.

134. Zhang Y, Murugesan P, Huang K, Cai H. NADPH oxidases and oxidase crosstalk in cardiovascular diseases: novel therapeutic targets. Nat Rev Cardiol. 2020;17(3):170-94. https://doi. org/10.1038/s41569-019-0260-8.

135. Davidson AM, Wysocki J, Batlle D. The interaction of SARSCoV-2 and other coronavirus with Angiotensin Converting Enzyme 2 (ACE2) as their main receptor: therapeutic implications. Hypertension. 2020. https://doi.org/10.1161/ hypertensionaha.120.15256.

136. Pranata R, Permana H, Huang I, Lim MA, Soetedjo NNM, Supriyadi R, et al. The use of renin angiotensin system inhibitor on mortality in patients with coronavirus disease 2019 (COVID-19): A systematic review and meta-analysis. Diabetes Metab Syndr. 2020;14(5):983-90. https://doi.org/10.1016/j.dsx.2020.06.047.

137. Baral R, White M, Vassiliou VS. Effect of Renin-AngiotensinAldosterone System Inhibitors in Patients with COVID-19: a Systematic Review and Meta-analysis of 28,872 Patients. Curr Atheroscler Rep. 2020;22(10):61. https://doi.org/10.1007/ s11883-020-00880-6.

138. Boakye D, Rillmann B, Walter V, Jansen L, Hoffmeister M, Brenner H. Impact of comorbidity and frailty on prognosis in colorectal cancer patients: A systematic review and meta-analysis. Cancer Treat Rev. 2018;64:30-9. https://doi.org/10.1016/j.ctrv.2018.02.003.

139. Tönjes A, Hoffmann A, Kralisch S, Qureshi AR, Klöting N, Scholz $\mathrm{M}$, et al. Pro-neurotensin depends on renal function and is related to all-cause mortality in chronic kidney disease. Eur J Endocrinol. 2020;183(3):233-44. https://doi.org/10.1530/eje-20-0087.

140. Qiu S, Cai X, Jia L, Sun Z, Wu T, Wendt J, et al. Does objectivelymeasured light-intensity physical activity reduce the risk of cardiovascular mortality? A meta-analysis. Eur Heart J Qual Care Clin Outcomes. 2020. https://doi.org/10.1093/ehjqcco/qcaa051.
141. Galdas P, Cheater F, Marshall P. What is the role of masculinity in white and South Asian men's decisions to seek medical help for cardiac chest pain? J Health Serv Res Policy. 2007;12(4):2239. https://doi.org/10.1258/135581907782101552.

142. Wambier CG, Goren A, Vaño-Galván S, Ramos PM, Ossimetha A, $\mathrm{Nau}$ G, et al. Androgen sensitivity gateway to COVID-19 disease severity. Drug Dev Res. 2020. https://doi.org/10.1002/ddr.21688.

143. Asselta R, Paraboschi EM, Mantovani A, Duga S. ACE2 and TMPRSS2 variants and expression as candidates to sex and country differences in COVID-19 severity in Italy. Aging (Albany NY). 2020;12(11):10087-98. https://doi.org/10.18632/aging.103415.

144. Vom Steeg LG, Dhakal S, Woldetsadik YA, Park HS, Mulka $\mathrm{KR}$, Reilly EC, et al. Androgen receptor signaling in the lungs mitigates inflammation and improves the outcome of influenza in mice. PLoS Pathog. 2020;16(7):e1008506. https://doi. org/10.1371/journal.ppat.1008506.

145. Corona G, Goulis DG, Huhtaniemi I, Zitzmann M, Toppari J, Forti G, et al. European Academy of Andrology (EAA) guidelines on investigation, treatment and monitoring of functional hypogonadism in males: Endorsing organization: European Society of Endocrinology. Andrology. 2020;8(5):97087. https://doi.org/10.1111/andr.12770.

146. Wittert G, Bracken K, Robledo KP, Grossmann M, Yeap BB, Handelsman DJ, et al. Testosterone treatment to prevent or revert type 2 diabetes in men enrolled in a lifestyle programme (T4DM): a randomised, double-blind, placebo-controlled, 2-year, phase 3b trial. Lancet Diabetes Endocrinol. 2021;9(1):32-45. https://doi.org/10.1016/s2213-8587(20)30367-3.

147. Poissy J, Goutay J, Caplan M, Parmentier E, Duburcq T, Lassalle F, et al. Pulmonary Embolism in Patients With COVID-19: Awareness of an Increased Prevalence. Circulation. 2020;142(2):184-6. https:// doi.org/10.1161/circulationaha.120.047430.

148. Klok FA, Kruip M, van der Meer NJM, Arbous MS, Gommers D, Kant KM, et al. Confirmation of the high cumulative incidence of thrombotic complications in critically ill ICU patients with COVID-19: An updated analysis. Thromb Res. 2020;191:14850. https://doi.org/10.1016/j.thromres.2020.04.041.

149. Grasselli G, Tonetti T, Protti A, Langer T, Girardis M, Bellani G, et al. Pathophysiology of COVID-19-associated acute respiratory distress syndrome: a multicentre prospective observational study. Lancet Respir Med. 2020. https://doi.org/10.1016/s22132600(20)30370-2.

150. Marietta M, Vandelli P, Mighali P, Vicini R, Coluccio V, D’Amico R. Randomised controlled trial comparing efficacy and safety of high versus low Low-Molecular Weight Heparin dosages in hospitalized patients with severe COVID-19 pneumonia and coagulopathy not requiring invasive mechanical ventilation (COVID-19 HD): a structured summary of a study protocol. Trials. 2020;21(1):574. https://doi.org/10.1186/s13063-020-04475-z.

151. Mahumud RA, Kamara JK, Renzaho AMN. The epidemiological burden and overall distribution of chronic comorbidities in coronavirus disease-2019 among 202,005 infected patients: evidence from a systematic review and meta-analysis. Infection. 2020:1-21. https://doi.org/10.1007/s15010-020-01502-8.

Publisher's Note Springer Nature remains neutral with regard to jurisdictional claims in published maps and institutional affiliations. 